OPEN ACCESS

Edited by: Arun K. Bhunia,

Purdue University, United States

Reviewed by:

Sujata Sirsat,

University of Houston, United States

Joelle K. Salazar,

U.S. Food and Drug Administration,

United States

*Correspondence:

Vivian C. H. Wu

vivian.wu@usda.gov

Specialty section:

This article was submitted to

Food Microbiology,

a section of the journal

Frontiers in Microbiology

Received: 25 September 2021

Accepted: 25 October 2021

Published: 09 December 2021

Citation:

Guan J, Lacombe A, Rane B,

Tang J, Sablani S and Wu VCH (2021)

A Review: Gaseous Interventions

for Listeria monocytogenes Control

in Fresh Apple Cold Storage.

Front. Microbiol. 12:782934.

do: $10.3389 /$ fmicb.2021.782934

\section{A Review: Gaseous Interventions for Listeria monocytogenes Control in Fresh Apple Cold Storage}

\author{
Jiewen Guan ${ }^{1,2}$, Alison Lacombe ${ }^{1}$, Bhargavi Rane ${ }^{1,2}$, Juming Tang ${ }^{2}$, Shyam Sablani ${ }^{2}$ and \\ Vivian C. H. Wu ${ }^{1 *}$
}

1 Produce Safety and Microbiology Research Unit, Western Regional Research Center, Agricultural Research Service, United States Department of Agriculture, Albany, CA, United States, ${ }^{2}$ Department of Biological Systems Engineering, Washington State University, Pullman, WA, United States

Listeria monocytogenes (L. monocytogenes) causes an estimated 1600 foodborne illnesses and 260 deaths annually in the U.S. These outbreaks are a major concern for the apple industry since fresh produce cannot be treated with thermal technologies for pathogen control before human consumption. Recent caramel apple outbreaks indicate that the current non-thermal sanitizing protocol may not be sufficient for pathogen decontamination. Federal regulations provide guidance to apple processors on sanitizer residue limits, organic production, and good manufacturing practices (GMPs). However, optimal methods to control L. monocytogenes on fresh apples still need to be determined. This review discusses L. monocytogenes outbreaks associated with caramel apples and the pathogen's persistence in the environment. In addition, this review identifies and analyzes possible sources of contaminant for apples during cold storage and packing. Gaseous interventions are evaluated for their feasibility for $L$. monocytogenes decontamination on apples. For example, apple cold storage, which requires waterless interventions, may benefit from gaseous antimicrobials like chlorine dioxide $\left(\mathrm{ClO}_{2}\right)$ and ozone $\left(\mathrm{O}_{3}\right)$. In order to reduce the contamination risk during cold storage, significant research is still needed to develop effective methods to reduce microbial loads on fresh apples. This requires commercial-scale validation of gaseous interventions and intervention integration to the current existing apple cold storage. Additionally, the impact of the interventions on final apple quality should be taken into consideration. Therefore, this review intends to provide the apple industry suggestions to minimize the contamination risk of $L$. monocytogenes during cold storage and hence prevent outbreaks and reduce economic losses.

Keywords: Listeria monocytogenes, food safety, fresh apples, cold storage, gaseous interventions

\section{INTRODUCTION}

Apples are one of the most valuable fruit crops in the United States (U.S.). The apple industry brings 5 billion dollars of revenue to the economy annually (U.S. Apple Association [USApple], 2021). In 2014, caramel apples contaminated with L. monocytogenes were linked to a foodborne illness outbreak in which 35 people across 12 U.S. states contracted listeriosis, 7 (20\%) of which 
died (U.S. Centers for Disease Control and Prevention [CDC], 2014). Apples are commonly consumed raw or minimally processed (Du et al., 2002). There is no "kill step" included in the fresh produce postharvest packing process to eliminate pathogenic bacteria. The current fresh apple industry relies heavily on postharvest washing to control foodborne pathogens. However, the most commonly used sanitizer, chlorine (hypochlorite), has been reported to react with organic matters to form carcinogenic compounds, raising health and environmental hazards (Artés et al., 2009).

During harvest, apples are picked by hand in the orchards and transported in bins to the packinghouse, where they are either cold-stored or washed, sized, sorted, and packed for the retail market. Unwashed apples are moved into refrigerated storage - either short-term conventional refrigeration or longterm controlled atmosphere (CA) (Pietrysiak et al., 2019). L. monocytogenes has the ability to grow at refrigeration temperatures and is persistent in a cold environment (Walker et al., 1990). The environmental testing of the caramel apple outbreak showed that the contamination was introduced on the apples at the firm's packing facility. Since then, several voluntary recalls have been reported for potential Listeria contaminations on fresh apples (U.S. Food and Drug Administration [FDA], 2017a, 2019a). These incidents show the need to improve current food safety systems in the apple packing industry. In particular, there is a need for developing and validating effective interventions to reduce contamination.

Several European countries such as Germany, Belgium, Denmark, Switzerland, and the Netherlands have banned chlorine in commercial produce washing (Artés et al., 2009; Shen et al., 2016). The efficacy of chlorine disinfection is highly dependent on the $\mathrm{pH}$ of the solution (Connell, 1996; Sun et al., 2019). Various environmentally friendly alternative sanitizers like chlorine dioxide, peracetic acid (PAA), and ozone have been suggested to replace chlorine (Rodgers et al., 2004; Hua et al., 2019; Guan et al., 2021). However, there has been limited information on the feasibility of those and other potential interventions for the apple industry.

Food safety interventions that minimize contamination risks are of critical importance. Therefore, the objective of this review is to identify the safety gaps during apple packing process and analyze the potential application of gaseous interventions in apple cold storage. An integrated approach to the existing apple packing facility is urgently needed. Currently, the federal agencies, the fresh apple industry, and researchers have switched their focus to gaseous interventions that decontaminate L. monocytogenes on fresh apples. This review will consider the regulatory requirements on gaseous interventions as well as organic production and handling of apples that could contribute to future industrial application and benefit the apple processors.

\section{LISTERIA MONOCYTOGENES}

\section{Listeria monocytogenes Outbreaks}

Listeriosis is a serious infection caused by the consumption of L. monocytogenes contaminated food. U.S. Centers for Disease Control and Prevention [CDC] (2021) reports that an estimated
1,600 people have been diagnosed with listeriosis yearly, and the death rate is about $16 \%$ in the U.S. Listeria monocytogenes is a gram-positive, facultative anaerobic pathogenic bacterium. It has the ability to replicate at refrigeration temperatures. These characteristics help L. monocytogenes adapt to produceassociated environments (e.g., cold storage) where other bacteria might be prohibited to grow (Du et al., 2002). For example, in the caramel apple outbreak in 2014, all fresh Granny Smith and Gala apples were voluntarily recalled because environmental testing revealed contamination with $L$. monocytogenes at the firm's apple-packing facility in California (U.S. Centers for Disease Control and Prevention [CDC], 2014). In January 2015, the U.S. Food and Drug Administration (FDA) conducted a traceback investigation. Six of the seven environmental samples positive for $L$. monocytogenes indistinguishable from the outbreak strains were isolated from food contact surfaces (FCS), including polishing brush, drying brushes, conveyor, and inside a wooden bin.

FDA investigation found the cross-contamination between FCS and apples likely played a role in the consecutive apple contamination in the outbreak. Thus, it has been hypothesized that L. monocytogenes contamination could happen throughout the packing process and the distribution chain. Once the pathogen is introduced to the environment, it is difficult to eliminate if appropriate good manufacturing practices (GMPs) are not applied. The Listeria-contaminated fresh produce caused foodborne illness and increased the food and economic loss for the produce industry, heightening awareness of food safety and implementing the Food Safety Modernization Act (FSMA). Fresh fruit growers, packers, and processors are required to adopt validated and effective preventive controls by the Produce Rule of the FSMA (U.S. Food and Drug Administration [FDA], 2011).

\section{Persistence in Environment}

There are many opportunities for L. monocytogenes to attach to the produce surface in a typical apple packing house. In the investigation of the cantaloupe and caramel apple outbreaks, environmental contamination at packing houses and equipment FCS were likely the source of listeriosis outbreaks (U.S. Centers for Disease Control and Prevention [CDC], 2011, 2014). These include cross-contamination during washing, the wax coating unit operation, cold storage, and FCS like polishing brushes and dryer rollers (Ruiz-Llacsahuanga et al., 2021). Cooling and packing operations may also be responsible for bacterial contamination of the produce due to the significant amount of water utilized during the packing process. Wet surface areas in packing facilities are favorable for bacterial growth (Pietrysiak et al., 2019). Water may facilitate biofilm development as one of the main locations, which enhances the persistence of L. monocytogenes in the environment (Galié et al., 2018). L. monocytogenes may spread in the environment and lead to food contamination, which emphasizes the importance of good agriculture practices (GAPs), good manufacturing practices (GMPs), and HACCP for the produce postharvest handling and processing (Farber et al., 2003). Therefore, it is critical to identify the safety gaps during the packing lines and implement preventive interventions to avoid contamination. 
Listeria monocytogenes has been isolated from soil, water, animal manure, and decaying vegetation (Farber and Peterkin, 1991; U.S. Food and Drug Administration [FDA], 2019b). Unlike other foodborne pathogens, L. monocytogenes can survive between a wide range of temperature $\left(-0.4\right.$ to $\left.50^{\circ} \mathrm{C}\right)$ and $\mathrm{pH}$ values (4.3 to 9.4) (Farber and Peterkin, 1991; Pietrysiak et al., 2019), and is resistant to adverse environmental conditions, such as low temperature, water activity or oxygen, and high acidity or salt (Buchanan and Phillips, 1990; Walker et al., 1990). The unique ability of $L$. monocytogenes to survive or even grow at low temperatures makes it a primary pathogen to contaminate fresh produce in refrigerated packing. L. monocytogenes persists in a produce packing environment from months to years, resulting in recontamination of the produce passing through that environment (Leong et al., 2017) and posing a high safety risk to the prolonged storage of fresh apples. The expression of cold shock proteins has been reported to help L. monocytogenes with the adaptation of low temperatures (Matereke and Okoh, 2020). Neunlist et al. (2005) concluded that the membrane lipids alteration of L. monocytogenes protects it from cold stress. In addition, whole-genome sequencing (WGS) showed that Listeria isolates from the voluntarily recalled whole apples, collected along the distribution chain, were highly related to the outbreak strains (U.S. Centers for Disease Control and Prevention [CDC], 2014; Angelo et al., 2017).

\section{Biofilm Formation}

Biofilms are complex structures composed of multiple cells embedded in an extracellular matrix that is mainly formed by polysaccharides, proteins, or extracellular DNA. This matrix can adhere to hard surfaces in a food processing environment, such as FCS (equipment, transport, storage surfaces, etc.) or food surfaces (vegetables, fruits, meat, etc.), responsible for the strong persistence of biofilm in the food industry. Biofilm formation offers the microbial cells higher physical resistance against desiccation, mechanical resistance against removal by liquid streams, and chemical resistance against antimicrobials and disinfectants (Galié et al., 2018). The presence of biofilm in food industry environments puts human health at risk. Thus, the food industry is seeking biofilm prevention and disruption methods.

Listeria monocytogenes biofilms are generally formed by teichoic acids. They can grow on major food contact surfaces, including stainless steel, low-density polyethylene (LDPE), polyvinyl chloride (PVC), polyester (PET), rubber, and glass surfaces throughout the food industry (Hua et al., 2019). Dygico et al. (2020) stated that factors like time, temperature, surface type, nutrient availability, and origin could affect the biofilm formation of $L$. monocytogenes. Then this pathogen can contaminate the food batches from the surfaces. With the replication ability at low temperatures, L. monocytogenes reinforces its hydrophilicity and induces biofilm formation as a response to cold temperatures, enhancing its attachment to surfaces and its resistance to sanitation procedures in food manufacturing plants. These characteristics highlight the great importance of inspecting and controlling L. monocytogenes biofilms in the food industry (Galié et al., 2018).

\section{FRESH APPLE PACKING PROCESS}

\section{After Harvest}

After being picked and transported from the orchard to the packing house, fresh apples are either directly washed and packed for shipment or stored in cold storage for future packing (Figure 1). Postharvest fungicide treatment (drenching or fogging) is often applied to fresh apples to avoid mold spoilage for extended storage time. However, the reuse of fungicide solutions in the drenching step may cause cross-contamination with pathogens like L. monocytogenes. Additionally, there is no elimination step to remove damaged apples (caused during harvest or transportation) before cold storage. The injured apples might promote the survival, growth, and spread of bacteria and fungus during storage (Ruiz-Llacsahuanga et al., 2021). Thus the preventive controls to reduce the microbial load on apples would be necessary to integrate into the cold storage before washing.

\section{Postharvest Washing}

Postharvest washing is a typical step to reduce contamination for most fresh produce, including processed (i.e., fresh-cut) produce. The aim of most produce washing sanitization on the commercial scale is a 3-log reduction of pathogens on foods and food contact surfaces (Gombas et al., 2017). Various washing steps are used for different apple varieties and fruit quality. Fresh apples in wooden/plastic harvest bins are dumped into flume tanks to remove soil and debris in packing lines. Sanitizers are usually added to the washing water, and the water quality is monitored to avoid cross-contamination. To prevent produce contamination, suitable antimicrobial agents are used, and several runs of freshwater wash are applied (Figure 1). The widely used antimicrobial agents are chlorine, peracetic acid (PAA), aqueous chlorine dioxide $\left(\mathrm{ClO}_{2}\right)$, aqueous ozone $\left(\mathrm{O}_{3}\right)$ and electrolyzed water (EW) (Murray et al., 2017; Sheng et al., 2020). The second flume wash is followed by a soap wash to further remove the dirt and disinfectant remaining on the surfaces. Spray washing intends to use higher pressure to wash off any chemicals or bacteria further.

The industry's gold-standard sanitizer is sodium hypochlorite for apple postharvest washing. However, the free chlorine reacts with the organic matter in the wash water, reducing efficacy before reaching its target pathogen. U.S. Food and Drug Administration [FDA] (2014) indicated that the commonly used concentrations of hypochlorite (50-200 ppm) maximumly achieve 1 to 2 log reductions on many produce commodities. For example, washing at a 200-ppm concentration of chlorine for $5 \mathrm{~min}$ resulted in a $0.6 \mathrm{log}$ reduction for L. monocytogenes on whole apples (Beuchat et al., 1998). Recently, potential Listeria contamination on fresh apples resulted in voluntary recalls in several states (U.S. Food and Drug Administration [FDA], 2017a, 2019a), suggesting the current washing protocols may not be sufficient for pathogen reduction.

Apples are dried after washing. A typical drying process often includes mild heat with blowing fans. Then, the apples are waxed with an edible coating to improve their appearance and slow down the decay of fresh apples. Before 


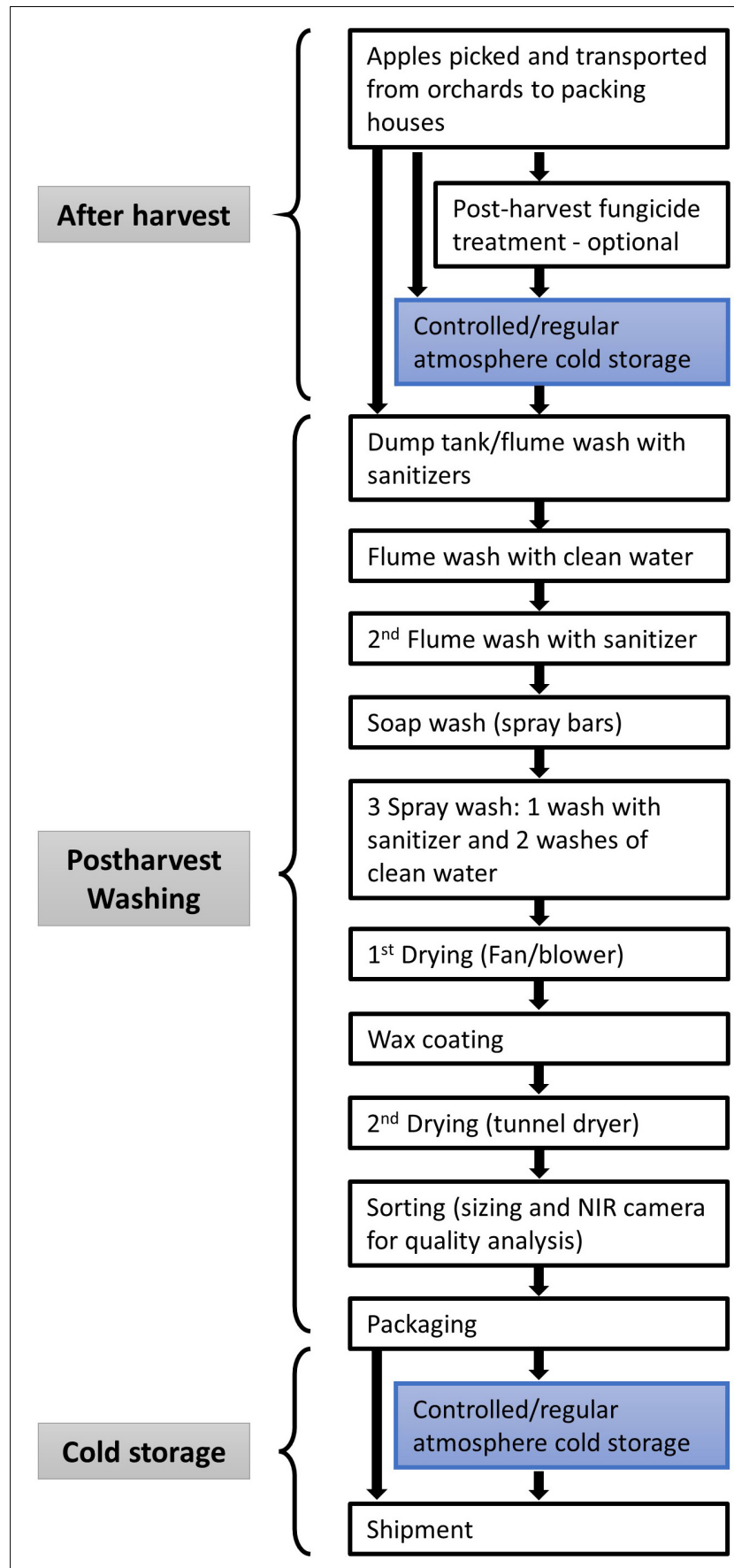

FIGURE 1 | Typical apple packing process in Washington, United States.

packaging, sizing, and near-infrared (NIR) cameras are used for quality analysis to reject the "bad" apples. After automatic packaging, apples are shipped to the retail markets with minimum storage during the distribution (Pietrysiak et al., 2019; Ruiz-Llacsahuanga et al., 2021).

The challenges on apple decontamination may be due to the naturally irregular shape and microstructures like lenticels (Figure 2), which shield bacteria from the sanitizing interventions (Pietrysiak and Ganjyal, 2018). Gaseous interventions like $\mathrm{ClO}_{2}$ have the ability to reach the bacteria harbored inside the lenticels, which could improve sanitation efficacy (Rane et al., 2021). Some lab-scale studies have shown effective log reductions of Listeria on apples (Du et al., 2002; Park and Kang, 2017). However, scaling up the methods to fit in the industrial processing line may be challenging due to the line setup and production scale.

\section{Cold Storage}

Two steps of cold storage may take place during the apple packing process (Figure 1). Firstly, the freshly picked apples may be stored in cold storage before they are washed and packaged where cross-contamination may be caused by the damaged apples or happen in environmental conditions (i.e., the facility and the environment). The second storage may happen after packaging before reaching the market. Even if sanitized by washing, the packed apples would contact with bacteria from the environment inside the storage room. The CA cold storage room provides refrigerated temperature, high relative humidity, low oxygen content, circulated air that can facilitate the survival of L. monocytogenes.

Controlled atmosphere (CA) was developed to provide an optimum environment (typically $1-2 \% \mathrm{O}_{2}, 1-3 \% \mathrm{CO}_{2}$, and $\mathrm{N}_{2}$ ) for keeping the freshness of fresh produce and increasing the length of storage by adjustment of normal air composition (78\% $\mathrm{N}_{2}, 21 \% \mathrm{O}_{2}, 0.03 \% \mathrm{CO}_{2}$ and other gases). A typical CA cold storage room setup is shown in Figure 3. Optimal CA cold storage reduces the respiration rate and ripening of fresh apples, resulting in maintaining the quality of fruit for up to 11 or 12 months (Farber et al., 2003; Sheng et al., 2018). However, regular atmosphere (RA) or CA cold storage has been designed mainly to extend the shelf-life of fresh apples. L. monocytogenes may survive those storage conditions, which becomes a food safety concern. For example, from a previous study (Sheng et al., 2017), L. monocytogenes on Fuji apples were decreased by $0.8-1.8 \log _{10}$ CFU/apple after 3 months of refrigerated atmosphere (RA) storage $\left(1,4\right.$, and $\left.10^{\circ} \mathrm{C}\right)$. Sheng et al. (2018) has reported that 30-week of CA cold storage led to 2.5-3.0 $\log _{10}$ CFU/apple reduction of L. innocua (surrogate bacteria of L. monocytogenes) on Fuji apples. Limited reductions of Listeria were observed in both studies. Therefore, RA or CA storage alone is ineffective at controlling Listeria on fresh apples, and additional antimicrobial interventions are needed during longterm storage.

\section{SAFETY GAPS DURING APPLE PACKING PROCESS}

Barrera et al. (2012) reported that the actual log reduction of the target pathogen was limited to 1-2 log CFU regardless of the sanitizer or washing time applied, which indicates that the efficacy of postharvest washing is minimal. Various studies showed that the factors that limited efficacy might include pathogen attachment, biofilm formation, and internalization into the plant. Another factor is the dynamics of organic 


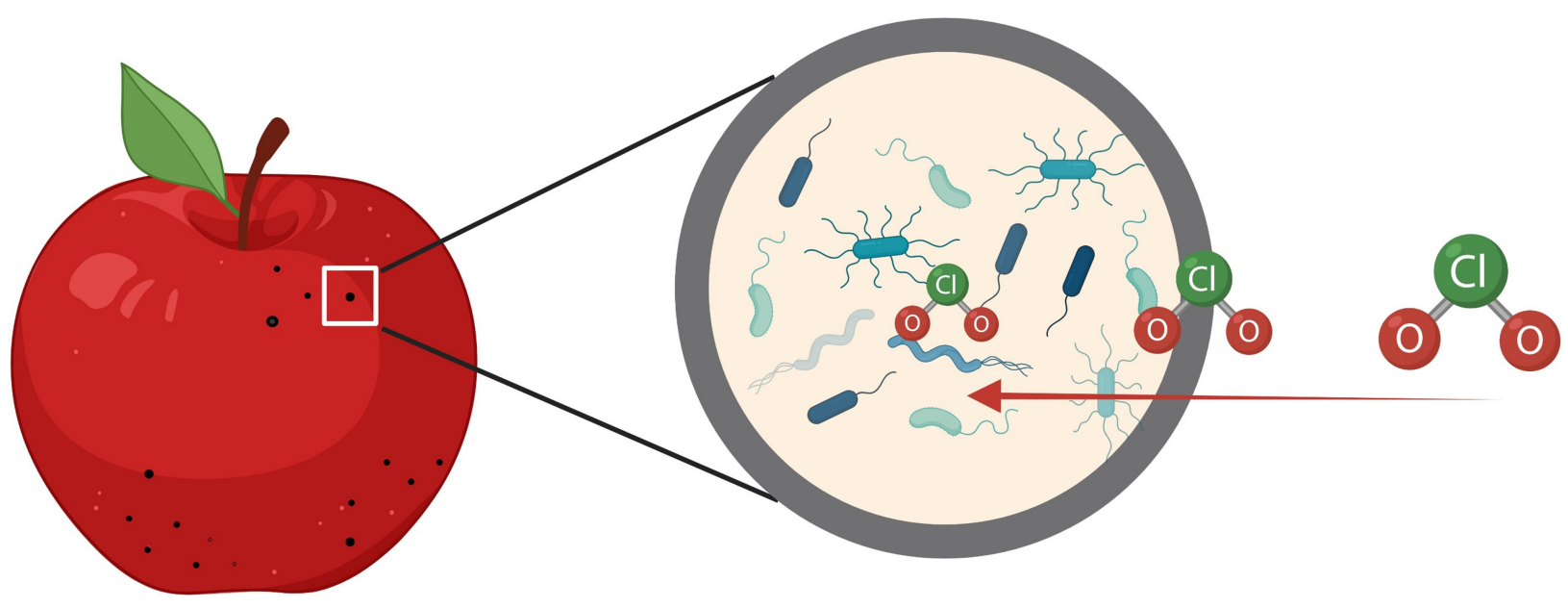

FIGURE 2 | Gaseous chlorine dioxide reaches the bacteria harbored inside the lenticels on apple surfaces.

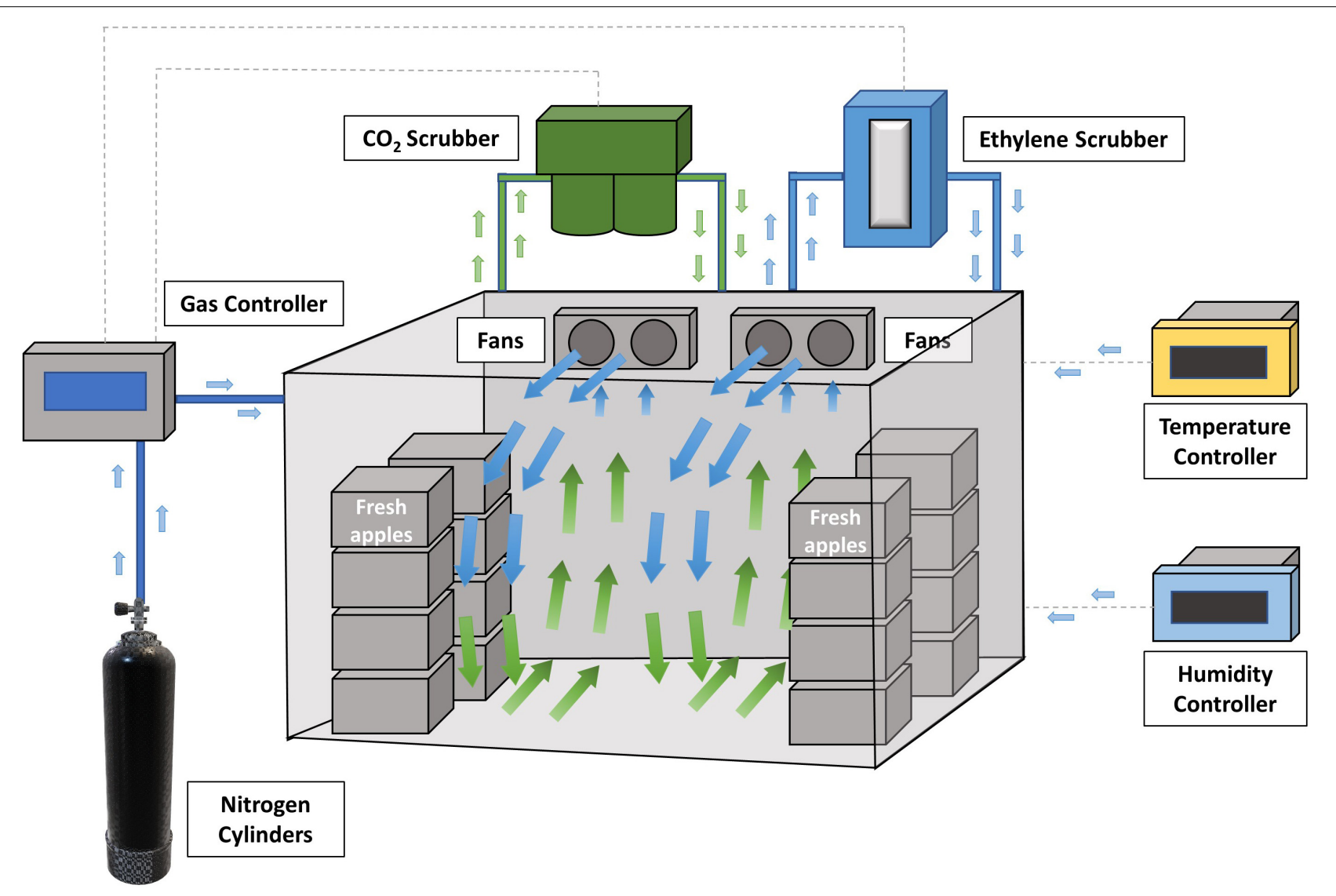

FIGURE 3 | Fresh apples are stored in a controlled atmosphere (CA) cold storage room (adopted from http://www.agroripe.com/controlled-atmosphere-storage/).

load in the washing flume, which harbors the pathogens from sanitizers and neutralizes part of the antimicrobials, especially relevant in chlorine wash (Shen et al., 2016). The research focus has transitioned from fresh produce decontamination to the prevention of cross-contamination. The concentration of active sanitizer in the wash flume, the quality of water, and organic load have been studied to improve the efficacy of washing, which is challenging in commercial validation (Gombas et al., 2017). Thus, washing itself is insufficient as part of a risk control and prevention approach. Additional or alternative interventions 
need to be explored and applied to control L. monocytogenes in the apple packing process.

Every year, about 4.2 billion pounds of fresh apples are stored in CA cold storage $\left(33-38^{\circ} \mathrm{F}\right)$ for up to 12 months, where apples are vulnerable to contamination with $L$. monocytogenes and spoilage microorganisms (Tree Top, 2019). Once contaminated, the apple surface is difficult to decontaminate because of its irregular shape, hydrophobic property, and presence of lenticels (Pietrysiak and Ganjyal, 2018). It is desirable to implement interventions during cold storage as preventive controls. The current existing gas systems in the CA cold storage provide an ideal environment to integrate gaseous interventions to reduce the microbial load on fresh apples. However, there are limited safety interventions implemented during CA cold storage. Furthermore, there is a knowledge gap on integrating current interventions into the CA storage system to ensure safety.

1-Methylcyclopropene (1-MCP) is a widely used inhibitor of ethylene receptors, which delays the ripening of fresh produce products. Commercial application of 1-MCP helps to reduce the ripening process, maintain quality, extend the shelf life of perishable fruits and vegetables (Menniti et al., 2006). 1-MCP can serve as a complementary strategy to CA cold storage to maintain a better quality of the fruit. Lum et al. (2017) reported that $1-\mathrm{MCP}$ in combination with CA cold storage effectively controlled physiologically disordered (senescent scald and internal breakdown) in certain cultivar pear fruits. Mattheis et al. (2017) studied the impacts of 1-MCP and CA storage on the development of bitter pit (physiological disorder) in 'Honeycrisp' apples. The results indicated that the use of 1-MCP and/or CA storage can potentially manage the development of bitter pit in 'Honeycrisp' apples. Even though 1-MCP fumigation has been combined with CA storage in the apple industry, both methods are applied to preserve food quality. The control of food safety during storage is still missing. Therefore, the integration of an antimicrobial gas to the CA storage can be a potential food safety intervention during the prolonged storage of fresh apples.

\section{POTENTIAL GASEOUS INTERVENTIONS DURING COLD STORAGE}

In the fresh produce packing industry, different applications of antimicrobial interventions exist throughout the process. Several review papers have summarized various decontamination methods presented in lab-scale studies and used in the fresh produce industry (Deng et al., 2019; Gurtler et al., 2019; Pietrysiak et al., 2019; Marik et al., 2020; Singh et al., 2021; Zhang et al., 2021). Most interventions are still focused on water treatment based on chlorine or alternatives. As water itself can become a pathogen carrier and provide favorable growth conditions for the pathogen, it is well worth outlining the waterless options for the inactivation of L. monocytogenes on fresh produce. As one of the waterless methods, gaseous interventions have the advantages to be integrated into the CA cold storage. Potential gaseous interventions include (1) gaseous $\mathrm{ClO}_{2}$; (2) gaseous $\mathrm{O}_{3}$; and (3) hurdle technology that combines multiple methods. Limited studies have been conducted on gaseous interventions during CA cold storage. Potential interventions that have been applied to fresh apples are summarized in Table $\mathbf{1 .}$

\section{Gaseous Chlorine Dioxide $\left(\mathrm{ClO}_{2}\right)$}

Gaseous $\mathrm{ClO}_{2}$ is a non-thermal and dry antimicrobial process that can be integrated into controlled atmosphere (CA) processes in order to extend shelf life and inactivate foodborne pathogens. There are several advantages of $\mathrm{ClO}_{2}$ over traditional chlorine wash (current industry practice), including a higher oxidative capacity $(2.5 \mathrm{x})$, enhanced antimicrobial efficacy on porous surfaces, no formation of carcinogenic trichloramine, and reduced corrosion of stainless-steel processing equipment ( $\mathrm{Wu}$ and Rioux, 2010). Moreover, its higher penetration into the harboring sites of microorganisms or irregular shape of the produce also contributes to the inactivation efficacy (Praeger et al., 2018; Deng et al., 2019).

Gaseous $\mathrm{ClO}_{2}$ has been reported to effectively decontaminate foodborne pathogens on various fresh produce (Bridges et al., 2018; Chai et al., 2020; Lacombe et al., 2020; Guan et al., 2021). Gaseous $\mathrm{ClO}_{2}$ has been utilized to disinfect L. monocytogenes and spoilage microorganisms on fresh apples on a lab scale by Du et al. (2002). This study achieved a reduction of 6.5-log CFU/spotted site L. monocytogenes on fresh apples ( $\mathrm{Du}$ et al., 2002). The survival of L. monocytogenes on different spots, including the calyx, stem cavity, and pulp surface of apples, was also studied. L. monocytogenes attached to the pulp skin were concluded to be further inactivated by gaseous $\mathrm{ClO}_{2}$. Park and Kang (2017) reported that gaseous $\mathrm{ClO}_{2}$ could achieve a $3.5 \log \mathrm{CFU} / \mathrm{cm}^{2}$ reduction of L. monocytogenes under 20 parts per million by volume (ppmv) for $15 \mathrm{~min}$. Lee et al. (2006) demonstrated that Alicyclobacillus acidoterrestis spores were reduced by 4.5 $\log$ CFU/apple by low release gaseous $\mathrm{ClO}_{2}$ sachet for $3 \mathrm{~h}$. Treatment with low-release $\mathrm{ClO}_{2}$ gas sachets did not affect the visual quality of apples, whereas medium and high release sachets helped with the development of small black spots on apple skin. Sy et al. (2005) studied the decay microorganisms' survival at $4.1 \mathrm{mg} / \mathrm{L}$ gaseous $\mathrm{ClO}_{2}$ treatment for $25 \mathrm{~min}$. A 1.68-log $\mathrm{CFU} /$ piece reduction of total yeasts and molds was achieved. The treated apples were consistently judged slightly but significantly ( $\alpha=0.05$ ) poorer in appearance, color, and overall quality. But the ratings from the sensory panel did not fall below "neither like nor dislike." These findings agree with the conclusion that gaseous $\mathrm{ClO}_{2}$ would effectively inactivate L. monocytogenes on fresh apples. However, it is not clear whether the apple quality was sacrificed and what $\mathrm{ClO}_{2}$ concentrations may damage the quality.

Decay microorganisms are one of the biggest industry concerns as they cause food waste and economic losses. Gaseous $\mathrm{ClO}_{2}$ has been reported to inactivate yeasts and molds, which may help to extend the shelf-life of apples. Application of gaseous $\mathrm{ClO}_{2}$ on reducing decay microorganisms of jujube fruit and kiwifruit in cold storage was studied by Park et al. (2019, 2020). An obvious increase in the quality of jujube fruit was observed with a reduction of 1.1-log CFU/g of total bacteria under $50 \mathrm{mg} / \mathrm{L}$ gaseous $\mathrm{ClO}_{2}$ at $2 \pm 1^{\circ} \mathrm{C}$ (Park et al., 2020). Similarly, Park et al. (2019) indicated that decay incidence and growth of microorganisms were reduced, and the ripening 
TABLE 1 | Gaseous food safety interventions for bacteria decontamination on fresh apples.

\begin{tabular}{|c|c|c|c|c|c|c|c|c|c|}
\hline Interventions & $\begin{array}{l}\text { Cold storage } \\
\text { highlighted }\end{array}$ & $\begin{array}{l}\text { Food } \\
\text { commodity }\end{array}$ & $\begin{array}{l}\text { Pathogen of } \\
\text { concern }\end{array}$ & Conditions & $\begin{array}{l}\text { Generation } \\
\text { method }\end{array}$ & $\begin{array}{l}\text { Sample } \\
\text { mass }\end{array}$ & Log reduction & $\begin{array}{l}\text { Impact on produce } \\
\text { quality }\end{array}$ & References \\
\hline \multicolumn{10}{|l|}{ Gaseous } \\
\hline \multirow[t]{8}{*}{$\begin{array}{l}\text { Chlorine } \\
\text { dioxide }\left(\mathrm{ClO}_{2}\right)\end{array}$} & & Fresh apples & $\begin{array}{c}\text { Listeria } \\
\text { monocytogenes }\end{array}$ & $\begin{array}{c}1-8 \mathrm{mg} / \mathrm{L} \\
10-30 \mathrm{~min}, 21^{\circ} \mathrm{C}, \\
\mathrm{RH}=90-95 \%\end{array}$ & $\mathrm{ClO}_{2}$ generator & 4 apples & $\begin{array}{l}\text { Calyx cavity: } 2.8-5.3 \text { log } \\
\text { CFU/spotted site; Stem } \\
\text { catity: } 2.2-5.0 \text { log } \\
\text { CFU/spotted site; Pulp } \\
\text { surface: } 3.5-6.5 \mathrm{log} \\
\text { CFU/spotted site. }\end{array}$ & $\mathrm{NM}^{*}$ & Du et al., 2002 \\
\hline & & Fresh apples & $\begin{array}{c}\text { Escherichia coli } \\
\text { O157:H7 }\end{array}$ & $\begin{array}{c}1.1-18.0 \mathrm{mg} / \mathrm{L}, \\
10-30 \mathrm{~min}, 21^{\circ} \mathrm{C}, \\
\mathrm{RH}=90-95 \%\end{array}$ & $\mathrm{ClO}_{2}$ generator & 4 apples & $\begin{array}{l}\text { Calyx cavity: } 2.1-6.5 \text { log } \\
\text { CFU/site; Stem catity: } \\
\text { 1.6-4.1 log CFU/site; Pulp } \\
\text { skin: } 2.8-7.3 \text { log CFU/site. }\end{array}$ & NM & Du et al., 2003 \\
\hline & & Fresh apples & Salmonella & $\begin{array}{c}1.4-4.1 \mathrm{mg} / \mathrm{L} \\
6-25 \mathrm{~min} \\
22 \pm 1^{\circ} \mathrm{C} \\
\mathrm{RH}=35-68 \%\end{array}$ & $\begin{array}{l}\mathrm{ClO}_{2} \text { gas } \\
\text { sachets }\end{array}$ & 3 apples & 3.21-4.21 log CFU/piece & $\begin{array}{l}\text { Subjective evaluation } \\
\text { revealed that treatment of } \\
\text { apples with } 4.1 \mathrm{mg} / \mathrm{L} \mathrm{ClO}_{2} \\
\text { gas for } 25 \mathrm{~min} \text { at } 58 \% \\
\text { relative humidity caused the } \\
\text { formation of small brown } \\
\text { spots on the skin. The } \\
\text { appearance of apples } \\
\text { treated with } 1.4 \text { and } \\
2.7 \mathrm{mg} / \mathrm{L} \mathrm{ClO}_{2} \text { at } 65 \text { to } \\
68 \% \text { relative humidity was } \\
\text { unaffected. }\end{array}$ & Sy et al., 2005 \\
\hline & & & $\begin{array}{l}\text { Total yeasts and } \\
\text { molds }\end{array}$ & & & & 1.09-1.68 log CFU/piece & & \\
\hline & & Fresh apples & $\begin{array}{l}\text { Alicyclobacillus } \\
\text { acidoterrestis }\end{array}$ & $\begin{array}{c}0.39-6.55 \mathrm{mg} / \mathrm{L} \\
\text { peak concentration, } \\
30 \mathrm{~min}-3 \mathrm{hrs} \\
22 \pm 2^{\circ} \mathrm{C}\end{array}$ & $\begin{array}{l}\mathrm{ClO}_{2} \text { gas } \\
\text { sachets }\end{array}$ & 1 apple & 2.7-5 log CFU/piece & $\begin{array}{l}\text { Treatment with low-release } \\
\mathrm{ClO}_{2} \text { gas sachets did not } \\
\text { affect the visual quality of } \\
\text { apples, whereas medium } \\
\text { and high-release sachets } \\
\text { helped develop small black } \\
\text { spots on apple skin. }\end{array}$ & Lee et al., 2006 \\
\hline & & Fresh apples & $\begin{array}{c}\text { Listeria } \\
\text { monocytogenes }\end{array}$ & $\begin{array}{c}20 \text { ppmv, } 5-15 \mathrm{~min}, \\
22 \pm 2^{\circ} \mathrm{C} \\
\mathrm{RH}=90 \pm 2 \%\end{array}$ & $\mathrm{ClO}_{2}$ generator & $\begin{array}{l}5 \times 2 \mathrm{~cm} \\
\text { pieces }\end{array}$ & $1.47-3.50 \mathrm{log} \mathrm{CFU} / \mathrm{cm}^{2}$ & NM & $\begin{array}{l}\text { Park and Kang, } \\
2017\end{array}$ \\
\hline & & & $\begin{array}{c}\text { Escherichia coli } \\
\text { O157:H7 }\end{array}$ & & & & $1.39-4.72 \mathrm{log} \mathrm{CFU} / \mathrm{cm}^{2}$ & & \\
\hline & & & $\begin{array}{l}\text { Salmonella } \\
\text { Typhimurium }\end{array}$ & & & & 1.25-3.95 log CFU/ $/ \mathrm{cm}^{2}$ & & \\
\hline Ozone $\left(\mathrm{O}_{3}\right)$ & Cold storage $\left(4-6^{\circ} \mathrm{C}\right)$ & Fresh apples & Fungi & $\begin{array}{l}1 \mu \mathrm{l} / \mathrm{L} \text { for } 1 \mathrm{~min} \\
\text { every } 12 \mathrm{hr} \\
84 \text { days, } 4-6^{\circ} \mathrm{C}\end{array}$ & $\mathrm{O}_{3}$ generator & $5 \mathrm{~kg}$ & $\begin{array}{l}\text { A larger portion of infected } \\
\text { apples within the group of } \\
\text { ozonated fruits. }\end{array}$ & $\begin{array}{l}\text { Ozone at } 1 \text { ppm was } \\
\text { unsuccessful in terms of } \\
\text { inhibition of fungal disease. } \\
\text { However, utilization of } \\
\text { ozone slowed down the } \\
\text { ripening of apples. }\end{array}$ & $\begin{array}{l}\text { Antos et al., } \\
2018\end{array}$ \\
\hline
\end{tabular}




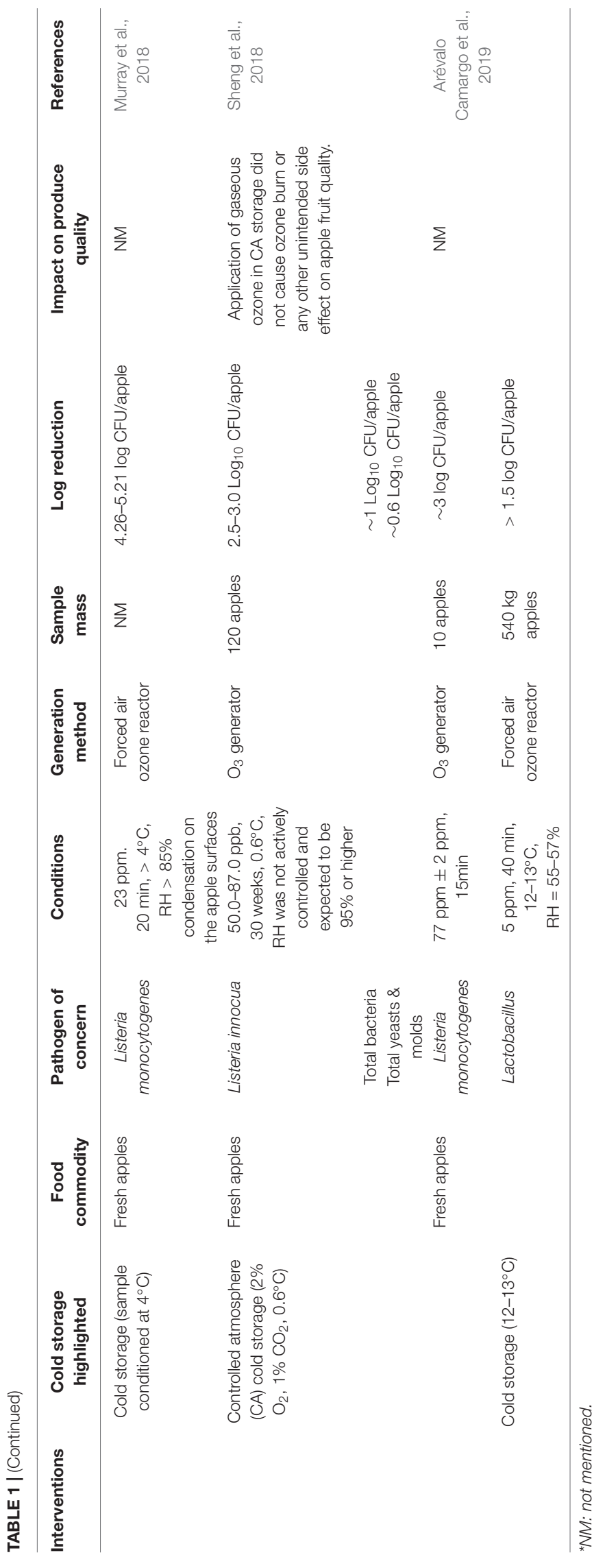

process was retarded under $30 \mathrm{mg} / \mathrm{L}$ gaseous $\mathrm{ClO}_{2}$ treatment for $30 \mathrm{~min}$. Reductions of $1 \mathrm{log} \mathrm{CFU} / \mathrm{g}, 1.4 \log \mathrm{CFU} / \mathrm{g}$, and $0.6 \log$ $\mathrm{CFU} / \mathrm{g}$ were achieved on total bacteria, total yeasts, and total molds of kiwifruit, respectively. These results demonstrated that gaseous $\mathrm{ClO}_{2}$ treatment during cold storage could be a promising decontamination method to reduce microbial load on fruits and maintain the quality.

However, there is a knowledge gap between lab-scale experiments and commercial-scale applications. Predictive models can be a useful tool to bridge the gap. The target reduction of 3-log of pathogens on foods and food contact surfaces and the lab-scale experimental data can be collected to establish the models (Gombas et al., 2017). By modeling the inactivation response of $L$. innocua under different doses, the amount of gaseous $\mathrm{ClO}_{2}$ needed in the scale-up study can be calculated via the models. The final step is to integrate gaseous $\mathrm{ClO}_{2}$ into the commercial $\mathrm{CA}$ cold storage for the decontamination of the Listeria-inoculated apples with the predicted conditions. As a result, the fresh apple industry can use the validated models and the engineering setup to apply gaseous $\mathrm{ClO}_{2}$ disinfection during their long-term CA storage.

\section{Gaseous Ozone $\left(\mathrm{O}_{3}\right)$}

Gaseous $\mathrm{O}_{3}$ is one of the most powerful oxidizers among food industrial-use sanitizers. The main advantages of $\mathrm{O}_{3}$ are the higher efficacy at low concentration over other antimicrobial agents and no residue formation because of decomposition to oxygen. Due to its high reactive and explosive character, $\mathrm{O}_{3}$ is unstable and can only be generated right before use. Numerous studies have demonstrated the efficacy of $\mathrm{O}_{3}$ inactivation on L. monocytogenes (Murray et al., 2018; Sheng et al., 2018).

Several studies integrated gaseous $\mathrm{O}_{3}$ into the RA or CA cold storage of fresh apples for bacteria inactivation. Murray et al. (2018) reported that $23 \mathrm{ppm}$ of forced air ozone treatment for $20 \mathrm{~min}$ could result in $3.07 \mathrm{log}$ CFU/apple reductions of L. monocytogenes on fresh apples taken out of the fridge at $4^{\circ} \mathrm{C}$. A commercial-scale ozone treatment on fresh apples was conducted to inactivate $L$. innocua and total bacteria, yeasts, and molds during CA cold storage. L. innocua was reduced by 3.0 $\log \mathrm{CFU} / \mathrm{apple}$ under $50-87 \mathrm{ppb}$ ozone treatment at $0.6^{\circ} \mathrm{C}$ for 30 weeks. Under the same condition, total bacteria and yeasts and molds were reduced approx. 1 and $0.6 \log$ CFU/apple, respectively. Application of gaseous ozone in CA storage did not cause ozone burn or any other unintended side effect on apple fruit quality (Sheng et al., 2018). Another commercialscale research was conducted by Arévalo Camargo et al. (2019). A forced-air ozone reactor was used during the cold storage of fresh apples to decontaminate Lactobacillus, which was selected and validated as the surrogate of $L$. monocytogenes in the same study. Two plastic vented bins containing $540 \mathrm{~kg}$ of apples were treated with $5 \mathrm{ppm}$ ozone for $40 \mathrm{~min}$, resulting in more than 1.5 $\log \mathrm{CFU} /$ apple reductions.

Even though gaseous ozone has been applied under semicommercial scale CA cold storage, ozone was found unstable since it decomposes fast after generation (Brodowska et al., 2018). In addition, a higher investment in equipment (generator and gas tanks) is required to set up the ozone system. As a strong oxidizer, 
ozone is more corrosive, particularly on rubber, plastics, and steel (Smilanick, 2003). In the past, gaseous ozone treatments have "burned" overexposed apples during long-term storage (Antos et al., 2018). Therefore, future studies are needed to overcome the difficulties and apply gaseous ozone to control L. monocytogenes in CA cold storage.

\section{Hurdle Technology}

Hurdle technology combines different methods to preserve a higher quality of fresh produce for extended shelf-life or to achieve higher efficacy of bacterial decontamination to enhance food safety. Studies on the effectiveness of hurdle technology (gaseous intervention involved) against bacteria on produce are summarized in Table 2. Gaseous $\mathrm{ClO}_{2}(50 \mathrm{mg} / \mathrm{L})$ and sodium diacetate $(200 \mathrm{mg} / \mathrm{kg})$ were combined with CA cold storage $\left(0 \pm 1^{\circ} \mathrm{C}\right)$ of fresh walnuts to control mold during $135 \mathrm{~d}$ of storage. CA cold storage plus $\mathrm{ClO}_{2}$ was the optimal treatment and kept the quality of fresh walnuts for $135 \mathrm{~d}$ at $0 \pm 1^{\circ} \mathrm{C}$, with the lowest mold incidence (5\%), the highest firmness and contents of fat and melatonin, as well as the maximum peroxidase activity (Ma et al., 2020). Park et al. (2018) reported a hurdle technology of $\mathrm{ClO}_{2}$ with $\mathrm{UV}-\mathrm{C}$ radiation to inactivate L. monocytogenes on spinach leaves and tomato surfaces. The combination of UVC and 10 ppmv $\mathrm{ClO}_{2}$ were applied on $5 \times 2 \mathrm{~cm}$ of samples (spinach leaves and tomatoes) for $20 \mathrm{~min}$, which resulted in $4.32 \mathrm{log} \mathrm{CFU} / \mathrm{g}$ reductions on spinach leaves and undetectable on tomato surfaces after treatment. In this study, the treatments did not significantly $(p>0.05)$ affect the color and texture of samples during storage at $7^{\circ} \mathrm{C}$ for 7 days. Therefore, the hurdle technology of multiple decontamination methods could potentially reduce L. monocytogenes in the apple packing process.

\section{FEDERAL REGULATIONS}

\section{Food Safety Modernization Act}

Ready-To-Eat (RTE) foods represent foods that are eaten without any further processing to reduce the microbiological hazards. RTE foods that have intrinsic characteristics (such as $\mathrm{pH}$ and water activity) can be natural or processed to prevent the growth of L. monocytogenes. As one of the RTE foods, apples are naturally preventing the growth of L. monocytogenes since the $\mathrm{pH}$ is less than 4.4 (U.S. Food and Drug Administration [FDA], 2017b). U.S. Food and Drug Administration [FDA] (2008) considers the adulteration of $L$. monocytogenes on a food product that contains more than 100 colony forming units (CFU) per gram of food when an RTE product does not support the growth of L. monocytogenes (Smith et al., 2018). Additionally, there is a zero-tolerance of L. monocytogenes if the RTE food supports L. monocytogenes growth.

Since fresh apples are considered both produce and Raw Agricultural Commodity (RAC), fresh apple packing house falls under the FDA Food Safety Modernization Act (FSMA) Final Produce Safety Rule (PSR). RAC means any food in its raw or natural state. All fruits, including fresh apples that are washed, colored, or treated in their unpeeled natural state prior to marketing, is considered as RAC (U.S. Food and Drug Administration [FDA], 2008). When a particular RAC is made into processed food, for example, irradiated papayas, the PSR applies only when the fresh papaya is a RAC before irradiation. When signed into law in 2011, FSMA highlighted the importance of preventive controls to reduce the incidence of food contamination that can lead to foodborne illness and outbreaks (U.S. Food and Drug Administration [FDA], 2011).

As a part of FSMA, PSR demonstrates the science-based requirements throughout the safe growing, harvesting, packing, and holding of produce grown for human consumption. The final rule went into effect in 2016. The rule requires the covered farms to take appropriate actions to minimize the risk of severe health consequences or death from the exposure to covered produce. It also requires the necessary prevention of the introduction of known or reasonably foreseeable hazards into the produce and providing suitable controls that save the produce from being adulterated. A Food Safety Plan (FSP), required by the FSMA Preventive Controls for Human Food (PCHF), documents a systematic approach to identify the food safety hazards that must be controlled to prevent or minimize the risk of foodborne illness. It is challenging for the produce industry to comply with the requirements since there is no "kill" step to eliminate pathogens. Therefore, identification of safety hazards and implementation of sufficient cleaning and sanitation preventive controls (i.e., safety interventions) draws great attention (U.S. Food and Drug Administration [FDA], 2016).

\section{Residue Limits}

The major $\mathrm{ClO}_{2}$ disinfectant by-products (DBPs) of concern are chlorite $\left(\mathrm{ClO}^{2-}\right)$ and chlorate $\left(\mathrm{ClO}_{3}{ }^{-}\right)$ions, with no direct formation of organohalogen DBPs. Unlike the other disinfectants, the major $\mathrm{ClO}_{2} \mathrm{DBP}$ are derived from the decomposition of the disinfectant as opposed to reaction with precursors (World Health Organization [WHO], 2000). The maximum contaminant level (MCL) of chlorite in drinking water, is $1.0 \mathrm{mg} / \mathrm{L}$ (U.S. Environmental Protection Agency [EPA], 2011).

In a recent study, the European Food Safety Authority investigated the presence of residues of chlorate in food and drinking water. The data showed that the chlorate exposure exceeded the tolerable daily intake has negatively impacted the iodine uptake, especially among infants and young children. In order to reduce the chlorate levels, the European Commission published new regulations of maximum residue levels for chlorate and perchlorate in foods in the summer of 2020. The maximum allowed level of chlorate on apples is $0.05 \mathrm{mg} / \mathrm{kg}$. Perchlorate mainly affects fruits and vegetables. The maximum allowed level is $0.05 \mathrm{mg} / \mathrm{kg}$. These new regulations highlighted the importance of monitoring chlorate and perchlorate residues after chlorine-based sanitation and reducing the concentration of disinfectant used in or on food products (European Commission [EC], 2020a,b).

Environmental Protection Agency Final Rule (EPA-HQOPP-2017-0063) was effective on December 26, 2018. 40 CFR Part 180 (Federal Register Number: 2018-27908) stated that "Residues of chlorate in or on tomato and cantaloupe are exempt 
TABLE 2 | Hurdle technologies (gaseous intervention involved) for bacteria decontamination on produce.

\begin{tabular}{llccccc}
\hline Interventions & $\begin{array}{c}\text { Cold storage } \\
\text { highlighted }\end{array}$ & $\begin{array}{c}\text { Food } \\
\text { commodity }\end{array}$ & $\begin{array}{c}\text { Pathogen of } \\
\text { concern }\end{array}$ & $\begin{array}{c}\text { Conditions } \\
\text { method }\end{array}$ & $\begin{array}{c}\text { Generation } \\
\text { Sample mass }\end{array} \quad$ Log reduction & $\begin{array}{c}\text { Impact on produce } \\
\text { quality }\end{array}$ \\
\hline
\end{tabular}

\section{technology}

Gaseous ozone

$\left(\mathrm{O}_{3}\right)$ and hot

water

Cantaloupe Mesophilic bacteria
melon

Water $\left(75^{\circ} \mathrm{C}\right)+$ air

dry $(15 \mathrm{~min})+\mathrm{O}_{3}$

(10,000 ppm, $30 \mathrm{~min}$,

$\left.11^{\circ} \mathrm{C}, \mathrm{RH}=90-95 \%\right)$

Chlorine
dioxide gas
$\left(\mathrm{ClO}_{2}\right)$ and
aerosolized
peracetic acid
(PAA)

PAA)

$\mathrm{ClO}_{2}$ gas and

freezing

Blueberry

Psychrotrophic

bacteria

Molds

Coliforms

Spinach leaves Escherichia coli

O157:H7

$80 \mathrm{ppm} \mathrm{PAA}+5 / 10$
${\mathrm{ppmv} \mathrm{ClO}_{2}}$

$5-20 \mathrm{~min}, 22 \pm 2^{\circ} \mathrm{C}$

$\mathrm{RH}=90 \pm 2 \% \quad$ ultrasonic

nebulizer

Salmonella

Typhimurium

Listeria

monocytogenes

Tomatoes

Escherichia coli

O157:H7

Salmonella

Typhimurium

Listeria

monocytogenes

Mesophilic aerobic

bacteria (MAB)

$\mathrm{ClO}_{2}$ gas $(4 \mathrm{mg} / \mathrm{L}$, $12 \mathrm{~h}, 12-$

$\left.14^{\circ} \mathrm{C}\right)+$ processing

+ freezing $\left(-20^{\circ} \mathrm{C}\right.$

quick, intermediate,

$$
\text { slow) }
$$

Yeasts and molds

$\mathrm{ClO}_{2}$ gas,

ultraviolet-C

(UV-C) light,

and fumaric

O157:H7

15-30 ppmv $\mathrm{ClO}_{2}$

gas, $0.5 \%$ fumaric acid, and $10 \mathrm{~kJ} / \mathrm{m}^{2}$ UV-C, 5-20 min, $\mathrm{RH}=80 \%$
$\mathrm{ClO}_{2}$ gas enerator + UV germicida
$\mathrm{ClO}_{2}$ sachet

16 lugs of

blueberries

( 9.1 kg/lug)

$5 \times 2 \mathrm{~cm}$

pieces

No evidence of damage Selma et al.,

in melons treated with hot 2008

combination and they maintained initial texture and aroma.

$5.1 \log$ CFU/g

$2.2 \log \mathrm{CFU} / \mathrm{g}$

$2.3 \log \mathrm{CFU} / \mathrm{g}$
0.9-5.4 log CFU/g

Combined treatment of

$\mathrm{ClO}_{2}$ gas (10 ppmv) and aerosolized PAA (80 ppm) did not significantly

$p>0.05$ ) affect the colo and texture of samples during 7 days of storage.

0.8-5.1 log CFU/g

0.3-4.1 log CFU/g

1.0-5.1 log CFU/g

0.9-5.2 log CFU/g

0.4-4.5 log CFU/g

$2 \log \mathrm{CFU} / \mathrm{g}$

$\mathrm{ClO}_{2}$ gassing followed by quick freezing effectively meets the current

microbiological standards

being imposed by buyers of frozen blueberries.

$1 \log \mathrm{CFU} / \mathrm{g}$

4.37-5.48 log CFU/g

The optimal treatment condition does not affect the quality of plum samples.

rk and Kang

2015

Zhang et al. 2015

2017

꿍

5.36-6.26 log CFU/g 
TABLE 2 | (Continued)

\begin{tabular}{|c|c|c|c|c|c|c|c|c|c|}
\hline Interventions & $\begin{array}{l}\text { Cold storage } \\
\text { highlighted }\end{array}$ & $\begin{array}{l}\text { Food } \\
\text { commodity }\end{array}$ & $\begin{array}{l}\text { Pathogen of } \\
\text { concern }\end{array}$ & Conditions & $\begin{array}{l}\text { Generation } \\
\text { method }\end{array}$ & Sample mass & Log reduction & $\begin{array}{c}\text { Impact on produce } \\
\text { quality }\end{array}$ & References \\
\hline \multirow[t]{2}{*}{$\begin{array}{l}\mathrm{ClO}_{2} \text { gas with } \\
\mathrm{UV}-\mathrm{C} \text { radiation }\end{array}$} & & Spinach leaves & $\begin{array}{c}\text { Listeria } \\
\text { monocytogenes }\end{array}$ & $\begin{array}{c}\text { UVC }+10 \mathrm{ppmv} \\
\mathrm{ClO}_{2} \text { gas, } 20 \mathrm{~min} \\
22 \pm 1^{\circ} \mathrm{C} \\
\mathrm{RH}=90 \pm 2 \%\end{array}$ & $\begin{array}{c}\mathrm{ClO}_{2} \\
\text { generator }+\mathrm{UV} \\
\text { lamp }\end{array}$ & $\begin{array}{c}5 \times 2 \mathrm{~cm} \text { in } \\
\text { size }\end{array}$ & $4.32 \pm 0.52 \log \mathrm{CFU} / \mathrm{g}$ & $\begin{array}{c}\text { Did not significantly } \\
\text { ( } \mathrm{p}>0.05 \text { ) affect the color } \\
\text { and texture of samples } \\
\text { during storage at } 7^{\circ} \mathrm{C} \text { for } \\
7 \text { days. }\end{array}$ & $\begin{array}{l}\text { Park et al., } \\
2018\end{array}$ \\
\hline & & $\begin{array}{l}\text { Tomato } \\
\text { surfaces }\end{array}$ & & & & $\begin{array}{c}5 \times 2 \mathrm{~cm} \\
\text { pieces }\end{array}$ & Not Detectable (ND) & & \\
\hline $\begin{array}{l}\mathrm{UV}+\text { gaseous } \\
\mathrm{O}_{3}+\text { hydrogen } \\
\text { peroxide }\end{array}$ & & Fresh apples & $\begin{array}{l}\text { Listeria } \\
\text { monocytogenes }\end{array}$ & $\begin{array}{c}\text { UV-C light (54-mJ } \\
\mathrm{cm}^{2} \text { dose), } 6 \%(\mathrm{v} / \mathrm{v}) \\
\text { hydrogen peroxide, } \\
2 \mathrm{~g} / \mathrm{h} \text { ozone, } \\
30-120 \mathrm{~s}, 48^{\circ} \mathrm{C}, \\
\mathrm{RH}>85 \%\end{array}$ & $\begin{array}{c}\text { UV-C } \\
\text { lamps + ozone- } \\
\text { emitting lamps } \\
+ \text { vaporizimg } \\
\text { unit }\end{array}$ & 3 apples & 3 log CFU/apple & $\mathrm{NM}^{*}$ & $\begin{array}{l}\text { Murray et al., } \\
2018\end{array}$ \\
\hline $\begin{array}{l}\text { Gaseous } \\
\mathrm{ClO}_{2}+\text { an } \\
\text { edible coating }\end{array}$ & Cold storage $\left(6^{\circ} \mathrm{C}\right)$ & Cantaloupe & Salmonella & $\begin{array}{c}\text { Gaseous } \mathrm{ClO}_{2} \\
\left(5 \mathrm{mg} / \mathrm{L}, 4.5 \mathrm{~h}, 6^{\circ} \mathrm{C},\right. \\
\mathrm{RH}=75 \%) \\
+ \text { NatureSeal edible } \\
\text { coating (NS) + cold } \\
\text { storage }\left(4^{\circ} \mathrm{C}\right)\end{array}$ & $\mathrm{ClO}_{2}$ generator & $\begin{array}{l}10 \text { whole } \\
\text { cantaloupes }\end{array}$ & $\begin{array}{c}\text { Negative for Salmonella } \\
\text { after } 21 \text { days of storage } \\
\text { (detection } \\
\text { limit = } 2 \mathrm{CFU} / \mathrm{g} \text { ) }\end{array}$ & $\begin{array}{l}\text { For the sensory quality } \\
\text { parameters analyzed } \\
\text { (color, water loss, and } \\
\text { texture), the samples } \\
\text { treated with NatureSeal } \\
\text { had significantly better } \\
\text { quality }(p>0.05 \text { ) than did } \\
\text { the control samples. }\end{array}$ & $\begin{array}{l}\text { Alicea et al., } \\
2018\end{array}$ \\
\hline \multirow[t]{3}{*}{$\begin{array}{l}\text { Gaseous } \\
\mathrm{ClO}_{2}+\text { cold } \\
\text { storage }\end{array}$} & Cold storage $\left(2^{\circ} \mathrm{C}\right)$ & Kiwifruit & Total bacteria & $\begin{array}{c}\mathrm{ClO}_{2}(30 \mathrm{mg} / \mathrm{L} \\
30 \mathrm{~min}, \mathrm{RH}=75- \\
80 \%)+2 \pm 1^{\circ} \mathrm{C}\end{array}$ & $\mathrm{ClO}_{2}$ generator & 270 fruits & $1 \log \mathrm{CFU} / \mathrm{g}$ & $\begin{array}{l}\text { Decay incidence and } \\
\text { growth of } \\
\text { microorganisms reduced, } \\
\text { and the ripening process } \\
\text { retarded. }\end{array}$ & $\begin{array}{l}\text { Park et al., } \\
2019\end{array}$ \\
\hline & & & Total yeasts & & & & $1.4 \log \mathrm{CFU} / \mathrm{g}$ & & \\
\hline & & & Total molds & & & & $0.6 \log$ CFU/g & & \\
\hline $\begin{array}{l}\text { Gaseous } \\
\mathrm{O}_{3}+\text { UV-C }\end{array}$ & & $\begin{array}{l}\text { Persimmon } \\
\text { fruits }\end{array}$ & Fungi & $\begin{array}{c}\mathrm{O}_{3}\left(9.81 \mathrm{mg} / \mathrm{m}^{3}\right. \\
1-24)+\mathrm{UV}-\mathrm{C} \\
(24 \mathrm{~cm}, 0.5 \mathrm{~h})\end{array}$ & $\begin{array}{l}\text { Activated } \\
\text { oxygen } \\
\text { generator }\end{array}$ & 6 fruits & $99.58-100 \%$ killing rate & $\begin{array}{l}\text { This non-thermal } \\
\text { sterilization could alleviate } \\
\text { astringency but hadn't } \\
\text { significant effects on } \\
\text { other properties, } \\
\text { including color, moisture } \\
\text { content, water activity, } \\
\text { and protopectin. }\end{array}$ & $\begin{array}{l}\text { Chen et al., } \\
2020\end{array}$ \\
\hline \multirow{2}{*}{$\begin{array}{l}\text { Gaseous } \\
\mathrm{ClO}_{2}+\text { cold } \\
\text { storage }\end{array}$} & Cold storage $\left(2^{\circ} \mathrm{C}\right)$ & Jujube fruit & Total bacteria & $\begin{array}{c}10,30,50 \mathrm{mg} / \mathrm{L} \\
2 \pm 1^{\circ} \mathrm{C}, \mathrm{RH}=80 \%\end{array}$ & $\mathrm{ClO}_{2}$ generator & $\begin{array}{c}5 \mathrm{~kg} \text { (35 fruits } \\
\text { per sample) }\end{array}$ & $1.1 \log \mathrm{CFU} / \mathrm{g}$ & $\begin{array}{c}\text { An obvious increase in } \\
\text { quality. }\end{array}$ & $\begin{array}{l}\text { Park et al., } \\
2020\end{array}$ \\
\hline & & & $\begin{array}{l}\text { Total yeasts and } \\
\text { molds }\end{array}$ & & & & Significantly reduced & & \\
\hline
\end{tabular}


TABLE 2 | (Continued)

\begin{tabular}{|c|c|c|c|c|c|c|c|c|c|}
\hline Interventions & $\begin{array}{l}\text { Cold storage } \\
\text { highlighted }\end{array}$ & $\begin{array}{l}\text { Food } \\
\text { commodity }\end{array}$ & $\begin{array}{l}\text { Pathogen of } \\
\text { concern }\end{array}$ & Conditions & $\begin{array}{l}\text { Generation } \\
\text { method }\end{array}$ & Sample mass & Log reduction & $\begin{array}{l}\text { Impact on produce } \\
\text { quality }\end{array}$ & References \\
\hline \multirow[t]{2}{*}{$\begin{array}{l}\text { Gaseous } \mathrm{ClO}_{2} \text { and } \\
\text { sodium diacetate } \\
\text { (SDA) }\end{array}$} & $\begin{array}{l}\text { Controlled atmosphere } \\
(\mathrm{CA}) \text { cold storage }(2 \% \\
\left.\mathrm{O}_{2}+25 \% \mathrm{CO}_{2}, 0^{\circ} \mathrm{C}\right)\end{array}$ & Fresh walnuts & Mold & $\begin{array}{c}\mathrm{CA}+50 \mathrm{mg} / \mathrm{L} \mathrm{ClO}_{2} \\
0 \pm 1^{\circ} \mathrm{C}, 135 \mathrm{~d} \\
\mathrm{RH}=70-80 \%\end{array}$ & $\begin{array}{c}\mathrm{ClO}_{2} \\
\text { powder + water }\end{array}$ & 200 fresh nuts & $\begin{array}{l}\text { Mold in the } \mathrm{CA}+\mathrm{SDA}, \\
\text { and } \mathrm{CA}+\mathrm{ClO}_{2} \\
\text { treatments were not } \\
\text { detected until day } 135\end{array}$ & $\begin{array}{l}\mathrm{CA}+\mathrm{ClO}_{2} \text { was the } \\
\text { optimal treatment and } \\
\text { kept the quality of fresh } \\
\text { walnuts for } 135 \mathrm{~d} \text { at } \\
0 \pm 1^{\circ} \mathrm{C} \text {, with the lowest } \\
\text { mold incidence (5\%), the } \\
\text { highest firmness, and } \\
\text { contents of fat and } \\
\text { melatonin, as well as the } \\
\text { maximum POD activity. }\end{array}$ & Ma et al., 2020 \\
\hline & & & & $\begin{array}{c}\mathrm{CA}+200 \mathrm{mg} / \mathrm{kg} \\
\mathrm{SDA}, 0 \pm 1^{\circ} \mathrm{C}, 135 \\
\mathrm{~d}, \mathrm{RH}=70-80 \%\end{array}$ & $\begin{array}{l}\text { Directly } \\
\text { purchased }\end{array}$ & & & & \\
\hline \multirow[t]{2}{*}{$\begin{array}{l}\text { Gaseous } \\
\mathrm{ClO}_{2}+\text { moisture } \\
+ \text { mild heat }\end{array}$} & & Almond & Salmonella & $\begin{array}{c}\mathrm{ClO}_{2}(20-\mathrm{g} \text { precursor } \\
\text { dose })+ \text { moisture } \\
\text { content }(7 \%)+\text { mild } \\
\text { heat }\left(40 \pm 1.5^{\circ} \mathrm{C}\right) \\
1-4 \mathrm{~h}\end{array}$ & $\mathrm{ClO}_{2}$ sachet & $400 \mathrm{~g}$ & $2.0 \log \mathrm{CFU} / \mathrm{g}$ & $\begin{array}{l}\text { No visual damages were } \\
\text { observed on almonds } \\
\text { post-treatment }\end{array}$ & $\begin{array}{l}\text { Rane et al., } \\
2021\end{array}$ \\
\hline & & & $\begin{array}{c}\text { Enterococcus } \\
\text { faecium NRRL } \\
\text { B-2354 }\end{array}$ & & & & $1.6 \log \mathrm{CFU} / \mathrm{g}$ & & \\
\hline \multirow[t]{3}{*}{$\begin{array}{l}\text { Gaseous } \mathrm{O}_{3} \\
+ \text { ultrasonic- } \\
\text { assisted } \\
\text { aerosolization } \\
\text { sanitizer }\end{array}$} & & Lettuce & $\begin{array}{c}\text { Escherichia coli } \\
\text { O157:H7 }\end{array}$ & $\begin{array}{c}\text { Gaseous } \mathrm{O}_{3} \text { (4 and } \\
8 \mathrm{ppm}, \\
3 \mathrm{~min})+ \text { sodium } \\
\text { hypochlorite (SH, } 100 \\
\text { and } 200 \mathrm{ppm}) / \text { acetic } \\
\text { acid (AA, } 1 \% \text { and } \\
2 \% \text { )/lactic acid (LA, } \\
1 \% \text { and } 2 \%)\end{array}$ & $\begin{array}{l}\text { Ozone } \\
\text { generator } \\
+ \text { ultrasonic- } \\
\text { assisted } \\
\text { nebulizer }\end{array}$ & $10 \mathrm{~g}$ & $0.7 \log \mathrm{CFU} / \mathrm{g}$ & $\begin{array}{l}\text { Quality analysis indicates } \\
\text { that LA + } 8 \text { ppm ozone } \\
\text { and } \mathrm{SH}+8 \mathrm{ppm} \text { ozone } \\
\text { did not negatively affect } \\
\text { color, polyphenolic } \\
\text { content, weight loss, and } \\
\text { sensory properties; } \\
\text { however, the levels of two } \\
\text { individual phenolic } \\
\text { responsible for } \\
\text { phenylpropanoid } \\
\text { synthesis were } \\
\text { significantly increased } \\
\text { after treatment with } 2 \% \\
\text { LA + } 8 \text { ppm ozone. }\end{array}$ & $\begin{array}{l}\text { Wang et al., } \\
2021\end{array}$ \\
\hline & & & $\begin{array}{l}\text { Salmonella } \\
\text { Typhimurium }\end{array}$ & & & & $0.75-1.28 \log \mathrm{CFU} / \mathrm{g}$ & & \\
\hline & & & $\begin{array}{c}\text { Listeria } \\
\text { monocytogenes }\end{array}$ & & & & $0.58 \log \mathrm{CFU} / \mathrm{g}$ & & \\
\hline $\begin{array}{l}\text { Gaseous } \mathrm{ClO}_{2}+1- \\
\text { methylciclopropene } \\
\text { (1-MCP) }\end{array}$ & Cold storage $\left(4^{\circ} \mathrm{C}\right)$ & Sweet cherry & Fungi & $\begin{array}{c}\mathrm{ClO}_{2}(30 \\
\mu \mathrm{L} / \mathrm{L})+1-\mathrm{MCP}(1 \\
\mu L / \mathrm{L}), 24 \mathrm{~h}, 4^{\circ} \mathrm{C}\end{array}$ & $\begin{array}{l}\text { Release from } \\
\text { solid } \\
\mathrm{ClO}_{2}+\text { release } \\
\text { from 1-MCP } \\
\text { powder } \\
\text { formulation }\end{array}$ & $4 \mathrm{~kg}$ & $\begin{array}{c}11.7 \% \text { decay incidence } \\
\text { (more than } 38.9 \% \\
\text { decrease) }\end{array}$ & $\begin{array}{l}\text { Better improve the } \\
\text { postharvest quality of } \\
\text { sweet cherry fruit. }\end{array}$ & $\begin{array}{l}\text { Zhao et al., } \\
2021\end{array}$ \\
\hline
\end{tabular}


from the requirement of a tolerance when resulting from the application of gaseous chlorine dioxide as a fungicide, bactericide, and antimicrobial pesticide," which allows for the expanded use of gaseous $\mathrm{ClO}_{2}$ on fresh produce. Other food commodities might be exempted with more data and scientific support in the future (U.S. Environmental Protection Agency [EPA], 2018).

\section{Organic Production and Handling}

The U.S. Department of Agriculture (USDA) has established a National Organic Program (NOP) rule to enforce organic production and handling requirements. The NOP provides the guidance of "The Use of Chlorine Materials in Organic Production and Handling" to state that approved chlorine materials may be utilized in direct contact with organic production according to label directions. Allowed chlorine materials in organic production are calcium hypochlorite, $\mathrm{ClO}_{2}$, and sodium hypochlorite. Chlorine use must be immediately followed by a rinse sufficient to reduce chlorine levels on the product to potable water levels at the maximum residual disinfectant level of $4 \mathrm{mg} / \mathrm{L}$ for chlorine (as $\mathrm{Cl}_{2}$ ) and $0.8 \mathrm{mg} / \mathrm{L}$ for $\mathrm{ClO}_{2}$, which is currently established by the Environmental Protection Agency (EPA) at $40 \mathrm{CFR} \S \S 141.2,141.65$ (U.S. Department of Agriculture [USDA], 2011; U.S. Environmental Protection Agency [EPA], 2011).

However, $\mathrm{ClO}_{2}$ is currently allowed for use in liquid solution in crop production as a preharvest algicide, disinfectant, and sanitizer, including in irrigation system cleaning systems (7 CFR $\$ 205.601(\mathrm{a})(2)(\mathrm{ii})$ ); in organic livestock production for use in disinfecting and sanitizing facilities and equipment (7 CFR $\S 205.603$ (a)(7)(ii)); and in organic handling for disinfecting and sanitizing food contact surfaces (7 CFR $\S 205.605(b)$ ). For these uses, residual chlorine levels in the water cannot exceed the maximum residual disinfectant limit under the Safe Water Drinking Act. A petition was submitted to NOP to extend the use of $\mathrm{ClO}_{2}$ in gaseous form for the antimicrobial treatment of products labeled "organic" or "made with organic [specified ingredients or food group(s)]" in 2015. This petition was transmitted to National Organic Standards Board (NOSB) in U.S. Department of Agriculture [USDA] (2018).

The current regulation status indicates that $\mathrm{ClO}_{2}$ in its liquid form under the guidance has been considered organic production, whereas in its gaseous form has not yet been approved. More studies on gaseous $\mathrm{ClO}_{2}$ and the demand for higher efficacy sanitation from the food industry may facilitate the approval of the petition.

$\mathrm{O}_{3}$, as one of the approved chemicals for use in organic postharvest systems, is considered GRAS (Generally Recognized as Safe) for produce and equipment disinfection. Exposure limits for worker safety apply (U.S. Department of Agriculture [USDA], 2011). The Occupational Safety and Health Administration (OSHA) regulates employee exposure to $\mathrm{O}_{3}$ gas through its Air Contaminants Standard, 29 CFR 1910.1000. The permissible exposure limit (PEL) is an 8-h, time-weighted average value of 0.1 part of $\mathrm{O}_{3}$ per million parts of air (ppm) (Occupational Safety and Health Administration [OSHA], 1994).

\section{CONCLUSION}

During the postharvest packing process, a heat-based lethal treatment cannot be applied to fresh produce like apples. As a persistent and pathogenic microorganism, L. monocytogenes has caused high risk contamination in fresh produce packing facilities in previous outbreaks. The current packing process mostly relies on postharvest washing has been reported to be insufficient for produce decontamination. Additionally, the longterm CA cold storage of fresh apples provides optimal conditions for Listeria growth and persistence. Therefore, potential safety interventions to inactivate L. monocytogenes during cold storage are in great need.

Waterless safety intervention and hurdle technology can be future directions to help improve the apple decontamination efficiency. Water treatment has brought numerous problems like reacting with organic loads, cross-contamination, and abundant water usage. In comparison, waterless treatments may avoid the problems and increase the effectiveness of the antimicrobials. However, waterless interventions might have different problems like residue allowance, workers' safety concerns, etc. The related regulations are still undergoing review. Both water and waterless treatments lack methodological standards, making it hard to compare data from different studies.

The integration of gaseous $\mathrm{ClO}_{2}$ into industrial $\mathrm{CA}$ cold storage offers critical food safety benefits for fresh apples by reducing the risk of pathogen contamination during storage. But it is necessary to ensure that $\mathrm{ClO}_{2}$ does not induce any lenticel breakdown nor bitter pit symptoms. Since the lenticels can harbor bacteria, thus protecting them from antimicrobial interventions, the gas interventions should inactivate pathogens without causing tissue damage. The overall fruit quality after gaseous $\mathrm{ClO}_{2}$ treatment needs to be inspected for any negative impact. Dry media generation of $\mathrm{ClO}_{2}$ avoids overdosing through control-released technology. However, there is a lack of knowledge with regards to the optimum initial dose to prevent any damage to the fruits. In addition, recent studies have concluded that a slow controlled release of $\mathrm{ClO}_{2}$ using dry precursors resulted in undetectable amounts of chlorate and chlorite residues (Smith and Scapanski, 2020). The lack of chemical residue is very important in order to maintain industry standards. The new commercial-scale integration system could augment GMP safety plans by reinforcing critical control points that rely heavily on postharvest washing. Apple growers and processors can use this in a storage decontamination step as part of the hurdle technology safety plans, helping to secure food safety and reduce food waste and economic losses. Therefore, gaseous $\mathrm{ClO}_{2}$ integrated into CA cold storage of fresh apples can potentially control L. monocytogenes.

Significant research is still greatly needed to develop effective methods to reduce microbial loads on fresh apples. Critical aspects, including surface characteristics of apples, commercial-scale validation of the intervention, intervention implementation/integration to the current existing apple packing process, and the impact of the interventions on final apple quality, should be taken into consideration. 


\section{AUTHOR CONTRIBUTIONS}

JG contributed to the conceptualization and design, reviewed the literature, prepared the figures and tables, and wrote the original draft of the manuscript. AL contributed to the conceptualization and design, and wrote, reviewed, and edited the manuscript. BR and SS wrote, reviewed, and edited the manuscript. JT supervised the data and wrote, reviewed, and edited the manuscript. VW contributed to the conceptualization, supervised the data, carried out the project administration,

\section{REFERENCES}

Alicea, C., Annous, B. A., Mendez, D. P., Burke, A., and Orellana, L. E. (2018). Evaluation of hot water, gaseous chlorine dioxide, and chlorine treatments in combination with an edible coating for enhancing safety, quality, and shelf life of fresh-cut cantaloupes. J. Food Protect. 81, 534-541. doi: 10.4315/0362-028X. JFP-17-392

Angelo, K. M., Conrad, A. R., Saupe, A., Dragoo, H., West, N., Sorenson, A., et al. (2017). Multistate outbreak of Listeria monocytogenes infections linked to whole apples used in commercially produced, prepackaged caramel apples: United States, 2014-2015. Epidemiol. Infect. 145, 848-856. doi: 10.1017/ S0950268816003083

Antos, P., Piechowicz, B., Gorzelany, J., Matłok, N., Migut, D., Józefczyk, R., et al. (2018). Effect of ozone on fruit quality and fungicide residue degradation in apples during cold storage. Ozone Sci. Eng. 40, 482-486. doi: 10.1080/01919512. 2018.1471389

Arévalo Camargo, J., Murray, K., Warriner, K., and Lubitz, W. (2019). Characterization of efficacy and flow in a commercial scale forced air ozone reactor for decontamination of apples. Lwt 113:108325. doi: 10.1016/j.lwt.2019. 108325

Artés, F., Gómez, P., Aguayo, E., Escalona, V., and Artés-Hernández, F. (2009). Sustainable sanitation techniques for keeping quality and safety of fresh-cut plant commodities. Post. Biol. Technol. 51, 287-296. doi: 10.1016/j.postharvbio. 2008.10.003

Barrera, M. J., Blenkinsop, R., and Warriner, K. (2012). The effect of different processing parameters on the efficacy of commercial postharvest washing of minimally processed spinach and shredded lettuce. Food Control 25, 745-751. doi: 10.1016/j.foodcont.2011.12.013

Beuchat, L. R., Nail, B. V., Adler, B. B., and Clavero, M. R. S. (1998). Efficacy of spray application of chlorinated water in killing pathogenic bacteria on raw apples, tomatoes, and lettuce. J. Food Protect. 61, 1305-1311. doi: 10.4315/0362-028X61.10 .1305

Bridges, D. F., Rane, B., and Wu, V. C. H. (2018). The effectiveness of closedcirculation gaseous chlorine dioxide or ozone treatment against bacterial pathogens on produce. Food Control 91, 261-267. doi: 10.1016/j.foodcont.2018. 04.004

Brodowska, A. J., Nowak, A., and Śmigielski, K. (2018). Ozone in the food industry: principles of ozone treatment, mechanisms of action, and applications: an overview. Crit. Rev. Food Sci. Nutr. 58, 2176-2201. doi: 10.1080/10408398.2017. 1308313

Buchanan, R. L., and Phillips, J. G. (1990). Response surface model for predicting the effects of temperature $\mathrm{pH}$, sodium chloride content, sodium nitrite concentration and atmosphere on the growth of Listeria monocytogenes. J. Food Protect. 53, 370-376. doi: 10.4315/0362-028x-53.5.370

Chai, H. E., Hwang, C. A., Huang, L., Wu, V. C. H., and Sheen, L. Y. (2020). Feasibility and efficacy of using gaseous chlorine dioxide generated by sodium chlorite-acid reaction for decontamination of foodborne pathogens on produce. Food Control 108:106839. doi: 10.1016/j.foodcont.2019.106839

Chen, X., Liu, B., Chen, Q., Liu, Y., and Duan, X. (2020). Application of combining ozone and UV-C sterilizations in the artificial drying of persimmon fruits. $L w t$ 134:110205. doi: 10.1016/j.lwt.2020.110205

Connell, G. (1996). The Chlorination/Chloramination Handbook. Denver, CO: American Water Works Association. funding acquisition, and resources, and wrote, reviewed, and edited the manuscript. All authors contributed to the article and approved the submitted version.

\section{FUNDING}

This work was supported by the United States Department of Agriculture National Institute of Food and Agriculture (USDA NIFA) Grant (grant number 2015-69003-32075).

Deng, L. Z., Mujumdar, A. S., Pan, Z., Vidyarthi, S. K., Xu, J., Zielinska, M., et al. (2019). Emerging chemical and physical disinfection technologies of fruits and vegetables: a comprehensive review. Crit. Rev. Food Sci. Nutr. 60, 2481-2508. doi: 10.1080/10408398.2019.1649633

Du, J., Han, Y., and Linton, R. H. (2002). Inactivation by chlorine dioxide gas $\left(\mathrm{ClO}_{2}\right)$ of Listeria monocytogenes spotted onto different apple surfaces. Food Microbiol. 19, 481-490. doi: 10.1006/fmic.2002.0501

Du, J., Han, Y., and Linton, R. H. (2003). Efficacy of chlorine dioxide gas in reducing Escherichia coli O157:H7 on apple surfaces. Food Microbiol. 20, 583591. doi: 10.1016/S0740-0020(02)00129-6

Dygico, L. K., Gahan, C. G. M., Grogan, H., and Burgess, C. M. (2020). The ability of Listeria monocytogenes to form biofilm on surfaces relevant to the mushroom production environment. Int. J. Food Microbiol. 317:108385. doi: 10.1016/j.ijfoodmicro.2019.108385

European Commission [EC] (2020a). Maximum Levels of Perchlorate in Certain Foods. Available online at: https://eur-lex.europa.eu/legal-content/EN/TXT/ $\mathrm{PDF}$ ? uri=CELEX:32020R0685\&qid=1591624227155\&from=EN (accessed 24 July 2021).

European Commission [EC] (2020b). Maximum Residue Levels for Chlorate in or on Certain Products. Available online at: https://eur-lex.europa. eu/legal-content/EN/TXT/PDF/?uri=CELEX:32020R0749\&rid=1 (accessed 24 July 2021).

Farber, J. M., and Peterkin, P. I. (1991). Listeria monocytogenes, a foodborne pathogen. Microbiol. Rev. 55, 476-511.

Farber, J. N., Harris, L. J., Parish, M. E., Beuchat, L. R., Suslow, T. V., Gorney, J. R., et al. (2003). Microbiological safety of controlled and modified atmosphere packaging of fresh and fresh-cut produce. Compreh. Rev. Food Sci. Food Safety 2, 142-160. doi: 10.1111/j.1541-4337.2003.tb00032.x

Galié, S., García-Gutiérrez, C., Miguélez, E. M., Villar, C. J., and Lombó, F. (2018). Biofilms in the food industry: health aspects and control methods. Front. Microbiol. 9:898. doi: 10.3389/fmicb.2018.00898

Gombas, D., Luo, Y., Brennan, J., Shergill, G., Petran, R., Walsh, R., et al. (2017) Guidelines to validate control of cross-contamination during washing of freshcut leafy vegetables. J. Food Protect. 80, 312-330. doi: 10.4315/0362-028X.JFP$16-258$

Guan, J., Lacombe, A., Tang, J., Bridges, D. F., Sablani, S., Rane, B., et al. (2021). Use of mathematic models to describe the microbial inactivation on baby carrots by gaseous chlorine dioxide. Food Control 123:107832. doi: 10.1016/j.foodcont. 2020.107832

Gurtler, J. B., Fan, X., Jin, T., and Niemira, B. A. (2019). Influence of antimicrobial agents on the thermal sensitivity of foodborne pathogens: a review. J. Food Protect. 82, 628-644. doi: 10.4315/0362-028X.JFP-18-441

Hua, Z., Korany, A. M., El-Shinawy, S. H., and Zhu, M.-J. (2019). Comparative evaluation of different sanitizers against Listeria monocytogenes biofilms on major food-contact surfaces. Front. Microbiol. 10:2462. doi: 10.3389/fmicb. 2019.02462

Kim, H. G., and Song, K. (2017). Combined treatment with chlorine dioxide gas, fumaric acid, and ultraviolet-C light for inactivating Escherichia coli O157:H7 and Listeria monocytogenes inoculated on plums. Food Control 71, 371-375. doi: 10.1016/j.foodcont.2016.07.022

Lacombe, A., Antosch, J. G., and Wu, V. C. H. (2020). Scale-up model of forced air-integrated gaseous chlorine dioxide for the decontamination of lowbush blueberries. J. Food Safety 40:e12793. doi: 10.1111/jfs.12793 
Lee, S. Y., Dancer, G. I, Chang, S., Rhee, M. S., and Kang, D. H. (2006). Efficacy of chlorine dioxide gas against Alicyclobacillus acidoterrestris spores on apple surfaces. Int. J. Food Microbiol. 108, 364-368. doi: 10.1016/j.ijfoodmicro.2005. 11.023

Leong, D., NicAogáin, K., Luque-Sastre, L., McManamon, O., Hunt, K., AlvarezOrdóñez, A., et al. (2017). A 3-year multi-food study of the presence and persistence of Listeria monocytogenes in 54 small food businesses in Ireland. Int. J. Food Microbiol. 249, 18-26. doi: 10.1016/j.ijfoodmicro.2017.02.015

Lum, G. B., DeEll, J. R., Hoover, G. J., Subedi, S., Shelp, B. J., and Bozzo, G. G. (2017). 1-Methylcylopropene and controlled atmosphere modulate oxidative stress metabolism and reduce senescence-related disorders in stored pear fruit. Postharvest Biol. Technol. 129, 52-63. doi: 10.1016/j.postharvbio.2017.03.008

Ma, Y., Li, P., Watkins, C. B., Ye, N., Jing, N., Ma, H., et al. (2020). Chlorine dioxide and sodium diacetate treatments in controlled atmospheres retard mold incidence and maintain quality of fresh walnuts during cold storage. Postharvest Biol. Technol. 161:11063. doi: 10.1016/j.postharvbio.2019.111063

Marik, C. M., Zuchel, J., Schaffner, D. W., and Strawn, L. K. (2020). Growth and survival of Listeria monocytogenes on intact fruit and vegetable surfaces during postharvest handling: a systematic literature review. J. Food Protect. 83, 108-128. doi: 10.4315/0362-028X.JFP-19-283

Matereke, L. T., and Okoh, A. I. (2020). Listeria monocytogenes virulence, antimicrobial resistance and environmental persistence: a review. Pathogens 9:528. doi: 10.3390/pathogens 9070528

Mattheis, J. P., Rudell, D. R., and Hanrahan, I. (2017). Impacts of 1methylcyclopropene and controlled atmosphere established during conditioning on development of bitter pit in 'Honeycrisp' apples. HortScience 52, 132-137. doi: 10.21273/HORTSCI11368-16

Menniti, A. M., Donati, I., and Gregori, R. (2006). Responses of 1-MCP application in plums stored under air and controlled atmospheres. Postharvest Biol. Technol. 39, 243-246. doi: 10.1016/j.postharvbio.2005.11.007

Murray, K., Moyer, P., Wu, F., Goyette, J. B., and Warriner, K. (2018). Inactivation of Listeria monocytogenes on and within apples destined for caramel apple production by using sequential forced air ozone gas followed by a continuous advanced oxidative process treatment. J. Food Protect. 81, 357-364. doi: 10. 4315/0362-028X.JFP-17-306

Murray, K., Wu, F., Shi, J., Jun Xue, S., and Warriner, K. (2017). Challenges in the microbiological food safety of fresh produce: limitations of postharvest washing and the need for alternative interventions. Food Qual. Safety 1, 289-301. doi: 10.1093/fqsafe/fyx027

Neunlist, M. R., Federighi, M., Laroche, M., Sohier, D., Delattre, G., Jacquet, C., et al. (2005). Cellular lipid fatty acid pattern heterogeneity between reference and recent food isolates of Listeria monocytogenes as a response to cold stress. Antonie Leeuwenhoek 88, 199-206. doi: 10.1007/s10482-005-5412-7

Occupational Safety and Health Administration [OSHA]. (1994). Occupational Safety and Health Administration's (OSHA) Regulations for Ozone. Available online at: https://www.osha.gov/laws-regs/standardinterpretations/1994-0929-0 (accessed 25 July 2021).

Park, H., Han, N., Kim, C. W., and Lee, U. (2019). Chlorine dioxide gas treatment improves the quality of hardy kiwifruit (Actinidia arguta) during storage. For. Sci. Technol. 15, 159-164. doi: 10.1080/21580103.2019.1636414

Park, H., Kim, C. W., Han, N., Jeong, M., and Lee, U. (2020). Gaseous chlorine dioxide treatment suppresses decay and microbial growth in coldstored jujube fruit. Hortic. Sci. Technol. 38, 860-869. doi: 10.7235/HORT.20 200078

Park, S. H., and Kang, D. H. (2015). Combination treatment of chlorine dioxide gas and aerosolized sanitizer for inactivating foodborne pathogens on spinach leaves and tomatoes. Int. J. Food Microbiol. 207, 103-108. doi: 10.1016/j. ijfoodmicro.2015.04.044

Park, S. H., and Kang, D. H. (2017). Influence of surface properties of produce and food contact surfaces on the efficacy of chlorine dioxide gas for the inactivation of foodborne pathogens. Food Control 81, 88-95. doi: 10.1016/j.foodcont.2017. 05.015

Park, S. H., Kang, J. W., and Kang, D. H. (2018). Inactivation of foodborne pathogens on fresh produce by combined treatment with UV-C radiation and chlorine dioxide gas, and mechanisms of synergistic inactivation. Food Control 92, 331-340. doi: 10.1016/j.foodcont.2018.04.059

Pietrysiak, E., and Ganjyal, G. M. (2018). Apple peel morphology and attachment of Listeria innocua through aqueous environment as shown by scanning electron microscopy. Food Control 92, 362-369. doi: 10.1016/j.foodcont.2018 .04 .049

Pietrysiak, E., Smith, S., and Ganjyal, G. M. (2019). Food safety interventions to control Listeria monocytogenes in the fresh apple packing industry: a review. Compreh. Rev. Food Sci. Food Safety 18, 1705-1726. doi: 10.1111/1541-4337. 12496

Praeger, U., Herppich, W. B., and Hassenberg, K. (2018). Aqueous chlorine dioxide treatment of horticultural produce: effects on microbial safety and produce quality-A review. Crit. Rev. Food Sci. Nutr. 58, 318-333. doi: 10.1080/10408398. 2016.1169157

Rane, B., Lacombe, A., Sablani, S., Bridges, D. F., Tang, J., Guan, J., et al. (2021). Effects of moisture content and mild heat on the ability of gaseous chlorine dioxide against Salmonella and Enterococcus faecium NRRL B-2354 on almonds. Food Control 123:107732. doi: 10.1016/j.foodcont.2020.107732

Rodgers, S. L., Cash, J. N., Siddiq, M., and Ryser, E. T. (2004). A comparison of different chemical sanitizers for inactivating Escherichia coli O157:H7 and Listeria monocytogenes in solution and on apples, lettuce, strawberries, and cantaloupe. J. Food Protect. 67, 721-731. doi: 10.4315/0362-028X-67.4.721

Ruiz-Llacsahuanga, B., Hamilton, A., Zaches, R., Hanrahan, I., and Critzera, F. (2021). Prevalence of Listeria species on food contact surfaces in Washington State Apple Packinghouses. Appl. Environ. Microbiol. 87:e02932-20. doi: 10. 1128/AEM.02932-20

Selma, M. V., Ibáñez, A. M., Allende, A., Cantwell, M., and Suslow, T. (2008). Effect of gaseous ozone and hot water on microbial and sensory quality of cantaloupe and potential transference of Escherichia coli O157:H7 during cutting. Food Microbiol. 25, 162-168. doi: 10.1016/j.fm.2007.06.003

Shen, C., Norris, P., Williams, O., Hagan, S., and Li, K. W. (2016). Generation of chlorine by-products in simulated wash water. Food Chem. 190, 97-102. doi: 10.1016/j.foodchem.2015.04.146

Sheng, L., Edwards, K., Tsai, H. C., Hanrahan, I., and Zhu, M. J. (2017). Fate of Listeria monocytogenes on fresh apples under different storage temperatures. Front. Microbiol. 8:1396. doi: 10.3389/fmicb.2017.01396

Sheng, L., Hanrahan, I., Sun, X., Taylor, M. H., Mendoza, M., and Zhu, M. J. (2018). Survival of Listeria innocua on Fuji apples under commercial cold storage with or without low dose continuous ozone gaseous. Food Microbiol. 76, 21-28. doi: 10.1016/j.fm.2018.04.006

Sheng, L., Shen, X., and Zhu, M. J. (2020). Screening of non-pathogenic surrogates of Listeria monocytogenes applicable for chemical antimicrobial interventions of fresh apples. Food Control 110:106977. doi: 10.1016/j.foodcont.2019. 106977

Singh, S., Maji, P. K., Lee, Y. S., and Gaikwad, K. K. (2021). Applications of gaseous chlorine dioxide for antimicrobial food packaging: a review. Environ. Chem. Lett. 19, 253-270. doi: 10.1007/s10311-020-01085-8

Smilanick, J. L. (2003). "Use of ozone in storage and packing facilities," in Proceedings of the Washington Tree Fruit Postharvest Conference, Wenatche, WA, 1-10.

Smith, A., Moorhouse, E., Monaghan, J., Taylor, C., and Singleton, I. (2018). Sources and survival of Listeria monocytogenes on fresh, leafy produce. J. Appl. Microbiol. 125, 930-942. doi: 10.1111/jam.14025

Smith, D. J., and Scapanski, A. (2020). Distribution and chemical Fate of [36Cl]chlorine dioxide gas on avocados, eggs, onions, and sweet potatoes. J. Agric. Food Chem. 68, 5000-5008. doi: 10.1021/acs.jafc.0c01466

Sun, X., Baldwin, E., and Bai, J. (2019). Applications of gaseous chlorine dioxide on postharvest handling and storage of fruits and vegetables-A review. Food Control 95, 18-26.

Sy, K. V., McWatters, K. H., and Beuchat, L. R. (2005). Efficacy of gaseous chlorine dioxide as a sanitizer for killing Salmonella, yeasts, and molds on blueberries, strawberries, and raspberries. J. Food Protect. 68, 1165-1175. doi: 10.4315/0362028X-68.6.1165

Tree Top (2019). U.S. Apple Crop Forecast 2019/20. Available online at: https://foodingredients.treetop.com/fruit-ingredients-blog/Post/U.S.-AppleCrop-Forecast-2019-2020/ (accessed 25 July 2021).

U.S. Apple Association [USApple] (2021). Industry at A Glance. Available online at: https://usapple.org/industry-at-a-glance (accessed August 05, 2021).

U.S. Centers for Disease Control and Prevention [CDC] (2011). Multistate Outbreak of Listeriosis Linked to Whole Cantaloupes from Jensen Farms, Colorado (FINAL UPDATE). Available online at: https://www.cdc.gov/listeria/ outbreaks/cantaloupes-jensen-farms/index.html (accessed 25 July 2021). 
U.S. Centers for Disease Control and Prevention [CDC] (2014). Multistate Outbreak of Listeriosis Linked to Commercially Produced, Prepackaged Caramel Apples Made from Bidart Bros. Apples (Final Update). Available online at: https: //www.cdc.gov/listeria/outbreaks/caramel-apples-12-14/index.html (accessed 11 July 2021).

U.S. Centers for Disease Control and Prevention [CDC] (2021). Listeria (Listeriosis). Available online at: https://www.cdc.gov/listeria/index.html (accessed 25 July 2021).

U.S. Department of Agriculture [USDA] (2011). National Organic Program (NOP) Guidance: The Use of Chlorine in Organic Production and Handling. Available online at: https://www.ams.usda.gov/sites/default/files/media/5026. pdf (accessed 24 July 2021).

U.S. Department of Agriculture [USDA], (2018). National Organic Standards Board Handling Subcommittee Petitioned Material Proposal Sodium Chlorite, for the Generation of Chlorine Dioxide Gas. Available online at: https://www.ams.usda.gov/sites/default/files/media/ HSSodiumChloriteChlorineDioxideGasPropOct2018Web.pdf (accessed 24 July 2021).

U.S. Environmental Protection Agency [EPA] (2011). 40 CFR part 141 National Primary Drinking Water Regulations. Available online at: https://www.epa.gov/sites/default/files/2015-11/documents/howepargulates_ cfr-2003-title40-vol20-part141_0.pdf (accessed 24 July 2021).

U.S. Environmental Protection Agency [EPA] (2018). Chlorate; Pesticide Exemptions From Tolerance. Available online at: https://www.federalregister. gov/documents/2018/12/26/2018-27908/chlorate-pesticide-exemptions-fromtolerance (accessed 25 July 2021).

U.S. Food and Drug Administration [FDA] (2008). COMPLIANCE POLICY GUIDE (CPG) Sec 555.320 Listeria monocytogenes. Available online at: https://www.fda.gov/regulatory-information/search-fda-guidancedocuments/cpg-sec-555320-listeria-monocytogenes\#III_B (accessed 25 July 2021).

U.S. Food and Drug Administration [FDA] (2011). Food Safety Modernization Act (FSMA). Available online at: https://www.fda.gov/food/guidance-regulationfood-and-dietary-supplements/food-safety-modernization-act-fsma (accessed 25 July 2021).

U.S. Food and Drug Administration [FDA] (2014). Chapter V. Methods to Reduce/Eliminate Pathogens from Produce and Fresh-Cut Produce. Available online at: http://wayback.archive-it.org/7993/20170111183954/http: //www.fda.gov/Food/FoodScienceResearch/SafePracticesforFoodProcesses/ ucm091363.htm (accessed 19 October 2020).

U.S. Food and Drug Administration [FDA] (2016). FSMA Final Rule on Produce Safety. Available online at: https://www.fda.gov/food/food-safetymodernization-act-fsma/fsma-final-rule-produce-safety (accessed 25 July 2021).

U.S. Food and Drug Administration [FDA] (2017a). Jack Brown Produce, Inc. Recalls Gala, Fuji, Honeycrisp and Golden Delicious Apples Due to Possible Health Risk. Available online at: https://www.fda.gov/safety/recallsmarket-withdrawals-safety-alerts/jack-brown-produce-inc-recalls-gala-fujihoneycrisp-and-golden-delicious-apples-due-possible-health (accessed 25 July 2021).

U.S. Food and Drug Administration [FDA] (2017b). Control of Listeria monocytogenes in Ready-To-Eat Foods: Guidance for Industry Draft Guidance. Available online at: https://www.fda.gov/files/food/published/Draft-Guidancefor-Industry--Control-of-Listeria-monocytogenes-in-Ready-To-Eat-Foods\%28PDF\%29.pdf (accessed 25 July 2021).
U.S. Food and Drug Administration [FDA] (2019a). North Bay Produce Voluntarily Recalls Fresh Apples Because of Possible Health Risk. Available online at: https://www.fda.gov/safety/recalls-market-withdrawals-safety-alerts/northbay-produce-voluntarily-recalls-fresh-apples-because-possible-health-risk (accessed 25 July 2021).

U.S. Food and Drug Administration [FDA] (2019b). Listeria (Listeriosis). Available online at: https://www.fda.gov/food/foodborne-pathogens/listerialisteriosis (accessed 25 July 2021).

Walker, S. J., Archer, P., and Banks, J. G. (1990). Growth of Listeria monocytogenes at refrigeration temperatures. J. Appl. Bacteriol. 68, $157-162$.

Wang, J., Zhang, Y., Yu, Y., Wu, Z., and Wang, H. (2021). Combination of ozone and ultrasonic-assisted aerosolization sanitizer as a sanitizing process to disinfect fresh-cut lettuce. Ultrason. Sonochem. 76:105622. doi: 10.1016/j. ultsonch.2021.105622

World Health Organization [WHO] (2000). Environmental Health Criteria 216 Disinfectants and Disinfectant By-Products. Available online at: http://apps.who.int/iris/bitstream/handle/10665/42274/WHO_EHC_216. pdf;jsessionid=B9CAC5ACDD3E141BC4A84A6FD48E9464? sequence $=1$ (accessed July 25, 2021).

Wu, V. C. H., and Rioux, A. (2010). A simple instrument-free gaseous chlorine dioxide method for microbial decontamination of potatoes during storage. Food Microbiol. 27, 179-184.

Zhang, L., Yan, Z., Hanson, E. J., and Ryser, E. T. (2015). Efficacy of chlorine dioxide gas and freezing rate on the microbiological quality of frozen blueberries. Food Control 47, 114-119. doi: 10.1016/j.foodcont.2014. 06.008

Zhang, W., Cao, J., and Jiang, W. (2021). Application of electrolyzed water in postharvest fruits and vegetables storage: a review. Trends Food Sci. Technol. 114, 599-607. doi: 10.1016/j.tifs.2021. 06.005

Zhao, H., Fu, M., Du, Y., Sun, F., Chen, Q., Jin, T., et al. (2021). Improvement of fruit quality and pedicel color of cold stored sweet cherry in response to pre-storage 1-methylciclopropene and chlorine dioxide treatments: combination treatment of $1-\mathrm{MCP}$ plus $\mathrm{ClO}_{2}$ improves postharvest quality of sweet cherry fruit. Sci. Hortic. 277:109806. doi: 10.1016/j.scienta.2020.1 09806

Conflict of Interest: The authors declare that the research was conducted in the absence of any commercial or financial relationships that could be construed as a potential conflict of interest.

Publisher's Note: All claims expressed in this article are solely those of the authors and do not necessarily represent those of their affiliated organizations, or those of the publisher, the editors and the reviewers. Any product that may be evaluated in this article, or claim that may be made by its manufacturer, is not guaranteed or endorsed by the publisher.

Copyright (อ 2021 Guan, Lacombe, Rane, Tang, Sablani and Wu. This is an openaccess article distributed under the terms of the Creative Commons Attribution License (CC BY). The use, distribution or reproduction in other forums is permitted, provided the original author(s) and the copyright owner(s) are credited and that the original publication in this journal is cited, in accordance with accepted academic practice. No use, distribution or reproduction is permitted which does not comply with these terms. 